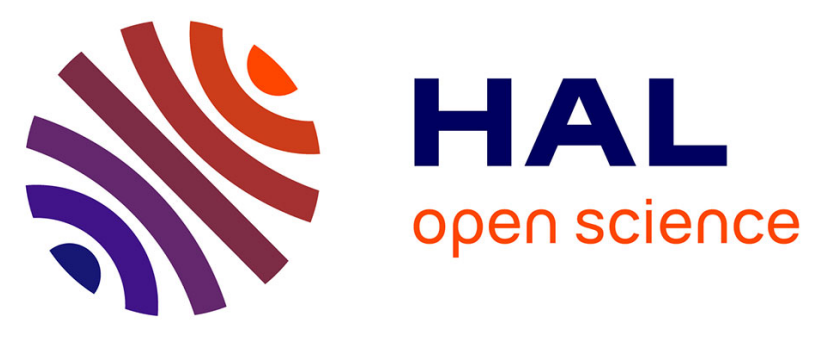

\title{
Iron and cobalt containing electrospun carbon nanofibre-based cathode catalysts for anion exchange membrane fuel cell
}

Andri Sokka, Marek Mooste, Maike Käärik, Viktoria Gudkova, Jekaterina Kozlova, Arvo Kikas, Vambola Kisand, Alexey Treshchalov, Aile Tamm, Päärn Paiste, et al.

\section{To cite this version:}

Andri Sokka, Marek Mooste, Maike Käärik, Viktoria Gudkova, Jekaterina Kozlova, et al.. Iron and cobalt containing electrospun carbon nanofibre-based cathode catalysts for anion exchange membrane fuel cell. International Journal of Hydrogen Energy, 2021, 46 (61), pp.31275-31287. 10.1016/j.ijhydene.2021.07.025 . hal-03334572

\section{HAL Id: hal-03334572 \\ https://hal.umontpellier.fr/hal-03334572}

Submitted on 4 Oct 2021

HAL is a multi-disciplinary open access archive for the deposit and dissemination of scientific research documents, whether they are published or not. The documents may come from teaching and research institutions in France or abroad, or from public or private research centers.
L'archive ouverte pluridisciplinaire HAL, est destinée au dépôt et à la diffusion de documents scientifiques de niveau recherche, publiés ou non, émanant des établissements d'enseignement et de recherche français ou étrangers, des laboratoires publics ou privés. 


\title{
Iron and cobalt containing electrospun carbon nanofibre-based cathode
}

\section{catalysts for anion exchange membrane fuel cell}

Andri Sokka ${ }^{\mathrm{a}}$, Marek Mooste ${ }^{\mathrm{a}}$, Maike Käärik ${ }^{\mathrm{a}}$, Viktoria Gudkova ${ }^{\mathrm{b}}$, Jekaterina Kozlova ${ }^{\mathrm{c}}$, Arvo Kikas $^{\mathrm{c}}$, Vambola Kisand ${ }^{\mathrm{c}}$, Alexey Treshchalov ${ }^{\mathrm{c}}$, Aile Tammc, Päärn Paiste ${ }^{\mathrm{d}}$, Jaan Aruväli ${ }^{\mathrm{d}}$, Jaan Leis ${ }^{\mathrm{a}}$, Andres Krumme ${ }^{\mathrm{b}}$, Steven Holdcroft ${ }^{\mathrm{e}}$, Sara Cavaliere ${ }^{\mathrm{f}, \mathrm{g}}$, Frédéric Jaouen ${ }^{\mathrm{f}}$, Kaido Tammeveski ${ }^{\mathrm{a}, *}$

${ }^{\mathrm{a}}$ Institute of Chemistry, University of Tartu, Ravila 14a, 50411 Tartu, Estonia

${ }^{\mathrm{b}}$ Department of Materials and Environmental Technology, Tallinn University of Technology, Ehitajate tee 5, 19086 Tallinn, Estonia

'Institute of Physics, University of Tartu, W. Ostwald Str. 1, 50411 Tartu, Estonia

${ }^{\mathrm{d}}$ Institute of Ecology and Earth Sciences, University of Tartu, Vanemuise 46, 51014 Tartu, Estonia

${ }^{\mathrm{e}}$ Department of Chemistry, Simon Fraser University, 8888 University Drive, Burnaby, BC, V5A 1S6,

Canada

fICGM, Univ. Montpellier, CNRS, ENSCM, Montpellier, France

${ }^{\mathrm{g}}$ Institut Universitaire de France (IUF), Paris, France

\begin{abstract}
The use of Pt-based cathode catalyst materials hinders the widespread application of anion exchange membrane fuel cells (AEMFCs). Herein, we present a non-precious metal catalyst (NPMC) material based on pyrolysed Fe and Co co-doped electrospun carbon nanofibres (CNFs). The prepared materials are studied as oxygen reduction reaction (ORR) and oxygen evolution reaction (OER) catalysts in alkaline and acidic environments. High activity towards the ORR in alkaline solution indicated the suitability of the prepared NPMCs for the application at the AEMFC cathode. In the AEMFC test, the membrane-electrode assembly bearing a cathode with the nanofibre-based catalyst prepared with the ionic liquid (IL) (Fe/Co/IL-CNF-800b) showed the maximum power density $\left(P_{\max }\right)$ of $195 \mathrm{~mW} \mathrm{~cm}^{-2}$, which is $78 \%$ of the $P_{\max }$ obtained with a commercial $\mathrm{Pt} / \mathrm{C}$ cathode catalyst. Such high ORR
\end{abstract}

\footnotetext{
${ }^{*}$ Corresponding author. Tel.: +372 7375168; E-mail address: kaido.tammeveski@ut.ee (K. Tammeveski).
} 
electrocatalytic activity was attributed to the unique CNF structure, high micro-mesoporosity, different nature of nitrogen species and metal- $\mathrm{N}_{\mathrm{x}}$ active centres.

Keywords: Carbon nanofibres; Electrospinning; Anion exchange membrane fuel cell; Nonprecious metal catalyst; Oxygen reduction; Electrocatalysis

\section{Introduction}

Carbon nanofibres (CNFs) as novel multifunctional materials have a large number of applications due to their unique structure, properties and functions. As an example, CNFs have been employed in the fields of nanotechnology, materials science, energy conversion and storage, environmental science and medicine. To prepare polymer nanofibres, electrospinning is an effective, facile, and easy-to-operate and scale-up technique that leans on static electricity $[1,2]$. Doped CNFs derived from electrospun polymer precursors have been widely studied for application in energy storage and conversion devices (e.g. supercapacitors, batteries, fuel cells and solar cells) [3-5]. The oxygen reduction reaction (ORR) is one of the key reactions in the fuel cells and metal-air batteries. Non $\square$ precious metal catalyst (NPMC) materials based on electrospun CNFs are very promising for ORR in terms of adjustable morphology, high electrical conductivity, tuneable porosity and excellent structural stability [6-8].

The ORR can proceed via $4 \mathrm{e}^{-}$or $2 \mathrm{e}^{-}$pathway giving water or hydrogen peroxide, respectively, as a final product [9]. Pt-based electrocatalysts are regarded currently as the most suitable for the ORR due to their unique characteristics, such as direct $4 \mathrm{e}^{-}$pathway, low overpotential and high current density in polymer electrolyte fuel cells and metal-air batteries $[7,9]$. In addition to ORR, the electrocatalysis of the oxygen evolution reaction (OER) is also essential for rechargeable metal-air batteries. Therefore, the bifunctionality of catalysts for both reactions is an important field of research for electrospun CNF-based NPMCs [3, 10-13]. 
According to the literature, the preparation of pyrolysed nanostructures composed of transition metal (TM) and nitrogen-doped electrospun CNFs is a favourable way to develop efficient and stable NPMCs for ORR [6,7]. In this case, single transition metal atoms coordinated to nitrogen $\left(\mathrm{M}-\mathrm{N}_{\mathrm{x}}\right)$ are embedded into the CNF and are active sites for the ORR. Also, the metallic particles wrapped in $\mathrm{N}-\mathrm{C}$ are beneficial for high ORR activity in alkaline media $[13,14]$. Furthermore, it has been found that when the CNF contains two or more TM dopants, its catalytic performance can be boosted [6]. Therefore, different research groups have prepared and studied $\mathrm{Zn} / \mathrm{Co}[15-17], \mathrm{Ni} / \mathrm{Co}[10,14,18]$ co-doped and even trimetallic $[13,19]$ electrospun CNF-based catalysts. As the single Fe or Co doped carbon nanomaterials show good ORR electrocatalytic performance [6], Co-Fe co-doped CNFs witness an increased interest. In more specific, Uhm et al. and Alegre et al. have proposed the use of Co and Fe codoped CNF catalysts in alkaline ethanol fuel cells [20] and rechargeable alkaline metal-air batteries [12], respectively. Li et al. have additionally tested their Co and Fe co-doped CNF in zinc-air battery (ZAB) and reported comparable results to $\mathrm{Pt} / \mathrm{C}$ [11]. In addition, CNF-based NPMCs co-doped with more than one TM have already shown considerable results in proton exchange membrane fuel cell (PEMFC) $[16,17]$. Until now however, there is no information available about $\mathrm{Co}$ and $\mathrm{Fe}$ co-doped electrospun CNF-based catalyst application at the cathode of anion exchange membrane fuel cells (AEMFCs). This research is appealing since cobalt ferrite nanoparticles supported on Vulcan carbon XC-72 cathode catalyst was recently shown to reach a remarkable peak power density $\left(P_{\max }\right)$ of $1350 \mathrm{~mW} \mathrm{~cm}^{-2}$ in AEMFC [21]. The versatility of electrospinning can be exploited by using porogens and additives in the precursor solution to further tune the inner porosity and structure of the obtained fibres. In our previous study on CNFs containing only one TM (Fe or Co) we investigated the influence of ionic liquids (ILs) as porogens in the electrospinning solution and demonstrated that the highest $P_{\max }$ was obtained for the catalyst prepared with the addition of IL [22]. 
In the present work, $\mathrm{Co}$ and $\mathrm{Fe}$ co-doped CNFs were prepared by electrospinning polyacrylonitrile (PAN) with acetate salts as TM precursors with and without the IL. The electrospun CNFs were further pyrolysed in $\mathrm{N}_{2}$ atmosphere and studied as ORR and OER electrocatalysts in alkaline and acidic media by rotating disc electrode method, and as a cathode catalyst in the AEMFC.

\section{Material and methods}

\subsection{Preparation of catalyst materials}

Two types of carbon nanofibre materials were prepared using a single $\square$ needle electrospinning setup and the rotating drum configuration similarly to our previous work [23]. The chemicals used were $1 \square$ butyl $\square 3 \square$ methylimidazolium acetate ([BMIm]OAc, IoLiTec), cobalt(II) acetate $\left(\mathrm{Co}(\mathrm{OAc})_{2}, 98 \%\right.$, Alfa Aesar $\left.{ }^{\mathrm{TM}}\right)$, iron(II) acetate $\left(\mathrm{Fe}(\mathrm{OAc})_{2}, 95 \%\right.$, Aldrich), polyacrylonitrile (PAN, MW=150,000, Sigma $\square$ Aldrich) and N,N-dimethylformamide (DMF, 99.8\%, SigmaAldrich). The electrospinning mixture in DMF for the first material (Fe/Co/IL-CNF) contained [BMIm] OAc:PAN: $\mathrm{Co}(\mathrm{OAc})_{2}: \mathrm{Fe}(\mathrm{OAc})_{2}$ (weight ratio of $\left.1: 7: 1: 1\right)$. In the case of the second material $(\mathrm{Fe} / \mathrm{Co}-\mathrm{CNF})$, the mixture of $\mathrm{PAN}: \mathrm{Co}(\mathrm{OAc})_{2}: \mathrm{Fe}(\mathrm{OAc})_{2}$ (weight ratio of 8:1:1) in DMF was used. Both electrospinning solutions were prepared under $\mathrm{N}_{2}$ atmosphere via mechanical stirring of $10 \mathrm{wt} \% \mathrm{PAN}$ in DMF at $40 \square$ for $72 \mathrm{~h}$. Then the other components were added and the mechanical stirring continued for additional 24-48 $\mathrm{h}$. The electrospinning conditions for $\mathrm{Fe} / \mathrm{Co}-\mathrm{CNF}$ were as follows: voltage $12 \mathrm{kV}$, distance to the collector (rotating drum) $10-10.5 \mathrm{~cm}$ and the feed rate of the solution $1.5 \mathrm{~mL} \mathrm{~h}^{-1}$. For the $\mathrm{Fe} / \mathrm{Co} / \mathrm{IL}-\mathrm{CNF}$, the voltage $12-14 \mathrm{kV}$, distance to the collector (rotating drum) $12-14 \mathrm{~cm}$ and the feed rate of the solution $0.6-1.0 \mathrm{~mL} \mathrm{~h}^{-1}$ were used. For both materials, the inner diameter of the needle was $0.1 \mathrm{~mm}$ and the speed of the drum $(7.5 \mathrm{~cm}$ diameter $)$ was $4400 \mathrm{rpm}$. 
After electrospinning, the materials were pyrolysed at 800,900 or $1000 \square$ under $\mathrm{N}_{2}$ atmosphere according to the previously published procedure [22]. The designation of the catalyst consists of the material followed by carbonisation temperature. Selected NPMCs were also leached in aqueous solution containing $0.5 \mathrm{M} \mathrm{H}_{2} \mathrm{SO}_{4}$ and $0.5 \mathrm{M} \mathrm{HNO}_{3}$ followed by a second pyrolysis in the same conditions as the first carbonisation. For acid treatment, two different sets of conditions were used. The additional letter $\mathrm{a}$ or $\mathrm{b}$ in the material designation stands for $8 \mathrm{~h}$ at $50{ }^{\circ} \mathrm{C}$ (procedure 1 ) or $12 \mathrm{~h}$ at $80{ }^{\circ} \mathrm{C}$ (procedure 2), respectively.

\subsection{Physical characterisation}

For physical characterisation, the NPMC materials were used in the form of powder or coated on a substrate material using catalyst inks without Nafion ${ }^{\circledR}$. The scanning electron microscopy (SEM) experiments were performed with a high $\square$ resolution scanning electron microscope (Helios NanoLab 600, FEI Company). For assessing the elemental composition of the samples and performing the elemental mapping, the INCA Energy 350 EDS spectrometer (Oxford Instruments) connected to the SEM was used. $\mathrm{X} \square$ ray photoelectron spectroscopy (XPS) studies were carried out at a pressure below $10^{-9}$ Torr using a SCIENTA SES $\square 100$ spectrometer with an electron take $\square$ off angle $90^{\circ}, 300 \mathrm{~W}$ non $\square$ monochromatic $\mathrm{Mg} \mathrm{K \alpha}$ $\mathrm{X} \square$ ray source and pass energy $200 \mathrm{eV}$. The obtained data were processed with the Casa XPS software (version 2.3.17). The processing included the removal of $\mathrm{X} \square$ ray satellites, peak fitting using the Gauss-Lorentz hybrid function, combination of linear and Shirley backgrounds and correction for electron spectrometer transmission.

Raman spectroscopy measurements in back-scattering geometry were carried out using a Renishaw inVia spectrometer with $514.5 \mathrm{~nm}$ excitation wavelength from the Ar ion laser and confocal microscope. To prevent overheating due to irradiation, the laser power on the sample was limited to $3 \mathrm{~mW}$. The 4-band fitting was used with the peaks of $\mathrm{G}\left(\sim 1580 \mathrm{~cm}^{-1}\right)$ - ideal 
graphitic lattice; D1 $\left(\sim 1350 \mathrm{~cm}^{-1}\right)$ - disordered graphitic lattice, graphene layer edge; D3 $\left(\sim 1500 \mathrm{~cm}^{-1}\right)$ - amorphous carbon and D4 $\left(\sim 1200 \mathrm{~cm}^{-1}\right)$ - disordered graphitic lattice [24]. A baseline correction was used to compensate for the small fluorescence background. The spectra were normalised to the intensity of the $\mathrm{G}$ band and the intensities of $I_{\mathrm{D} 1}$ and $I_{\mathrm{G}}$ (integrated areas under the bands) as well as FWHM of D1 and G bands were extracted from the fitting of the curves by Voigt functions.

The composition of the catalysts crystalline phases was studied using the powder X-ray diffraction (XRD) analysis with a Bruker D8 Advance diffractometer employing Ni-filtered $\mathrm{Cu} \mathrm{K} \alpha$ radiation. The XRD patterns were registered using a step of $0.013^{\circ} 2 \theta$ from 5 to $85^{\circ} 2 \theta$ and the collecting time of $525 \mathrm{~s}$ per step.

For the microwave plasma atomic emission spectroscopy (MP $\square$ AES) analysis, the samples were dissolved with Anton Par Multiwave PRO microwave digestion system using NXF100 digestion vessels (PTFE $\square$ TFM liner) in $8 \mathrm{~N}$ rotor prior to analysis. $10 \mathrm{mg}$ of sample was weighed into PTFE vessels into which $4 \mathrm{ml}$ of $69 \% \mathrm{HNO}_{3}$ (Carl Roth ROTIPURAN Supra) and $2 \mathrm{ml}$ of $\mathrm{H}_{2} \mathrm{O}_{2}$ (Sigma-Aldrich TraceSelect) were sequentially added. After the initial reaction had subsided the vessels were capped and digested in the microwave unit at $240{ }^{\circ} \mathrm{C}$ and 45-50 bar. After digestion the samples were diluted using $2 \% \mathrm{HNO}_{3}$ to a final concentration of around $4 \mathrm{mg} \mathrm{L}^{-1}$ and analysed using Agilent MP-AES 4210. Concentrations were determined using analytical wavelengths Co $350.631 \mathrm{~nm}, \mathrm{Fe} 371.993 \mathrm{~nm}$.

The porosity parameters of the materials were found using low-temperature $\mathrm{N}_{2}$ physisorption with NOVAtouch LX2 (Quantachrome Instruments). Prior to measurements, the samples were degassed under vacuum at $300{ }^{\circ} \mathrm{C}$ for $12 \mathrm{~h}$. The BET surface area $\left(S_{\mathrm{BET}}\right)$ [25] of samples was calculated in the $P / P_{0}$ interval of $0.02-0.2$. The total pore volume $\left(V_{\text {tot }}\right)$ was calculated at $P / P_{0}$ 0.97. Specific surface area $\left(S_{\mathrm{dft}}\right)$, volume of micropores $\left(V_{\mu}\right)$ and pore size distribution 
(PSD) were calculated from $\mathrm{N}_{2}$ adsorption/desorption isotherms using a quenched solid density functional theory (QSDFT) equilibria model for slit type pores.

\subsection{Electrochemical experiments}

The electrochemical experiments were performed using cyclic voltammetry $(\mathrm{CV})$ and rotating disc electrode (RDE) methods in Ar-saturated (99.999\%, Linde) or $\mathrm{O}_{2}$-saturated (99.999 \%, Linde) $0.1 \mathrm{M} \mathrm{KOH}$ (p.a. quality, Merck) or $0.5 \mathrm{M} \mathrm{H}_{2} \mathrm{SO}_{4}$ (Suprapur, Merck) solutions. The catalyst inks with Nafion ${ }^{\circledR}$ were prepared in 2-propanol (99.8 \%, Honeywell Riedel-de Haën) similarly as in our previous study [26]. After drop-casting the ink onto the polished and cleaned [27] glassy carbon (GC, $A=0.196 \mathrm{~cm}^{2}$ ) electrodes (GC-20SS, Tokai Carbon, Japan), the NPMC loading of 0.2 and $0.8 \mathrm{mg} \mathrm{cm}^{-2}$ was used for the experiments in alkaline and acidic media, respectively. In the case of the commercial $\mathrm{Pt} / \mathrm{C}(46.1 \mathrm{wt} \% \mathrm{Pt}$, Tanaka Kikinzoku Kogyo K.K., Japan) catalyst, a $20 \mu \mathrm{g}_{\mathrm{Pt}} \mathrm{cm}^{-2}$ loading was used [22]. The electrochemical experiments were conducted in a 3-electrode glass cell using Autolab potentiostat/galvanostat PGSTAT30 (Metrohm Autolab, The Netherlands), Nova 2.1 software, EDI101 rotator and CTV101 (Radiometer) speed control unit. Pt-wire served as a counter electrode and saturated calomel electrode (SCE) as the reference electrode. All the reported potentials are referred with respect to the SCE. The polarisation curves for oxygen reduction and evolution reaction were recorded in the cathodic and anodic direction, respectively. The polarisation curves were iR compensated using the ohmic resistance values obtained with electrochemical impedance spectroscopy [28].

\subsection{AEMFC testing}

The membrane-electrode assembly (MEA) was prepared using poly[2,2'-(2,2",4,4",6,6"hexamethyl-p-terphenyl-3,3"'-diyl)-5,5'-bibenzimidazole] (HMT-PMBI) anion exchange 
membrane (AEM) with benzimidazolium cationic groups [29], gas-diffusion layer (GDL, Sigracet 28BC), NPMC or Pt/C at the cathode and Pt-Ru/C (50:25:25 by weight, Alfa Aesar) at the anode. According to the previously published procedure $[22,26]$, the catalyst loadings of $2 \mathrm{mgNPMC}_{\mathrm{NP}} \mathrm{cm}^{-2}$ (or $0.4 \mathrm{mg}_{\mathrm{Pt}} \mathrm{cm}^{-2}$ ) and $0.6 \mathrm{mg}_{\mathrm{Pt}-\mathrm{Ru}} \mathrm{cm}^{-2}$ at the gas diffusion electrodes were used for cathode and anode, respectively. The catalyst-coated GDL and the AEM were immersed overnight in $3 \mathrm{M} \mathrm{KOH}$ prior to assembling the MEA and sandwiching it into a 5 $\mathrm{cm}^{2}$ cell (Fuel Cell Technologies Inc., USA) with silicone gaskets and a torque of $7 \mathrm{Nm}$. The performance of the prepared MEA was studied in a Greenlight Fuel Cell Test Station (G50 Fuel Cell System, Hydrogenics, Canada). During the testing, a flow rate of 0.05 NLPM for humidified $(80 \% \mathrm{RH}) \mathrm{H}_{2}$ and $\mathrm{O}_{2}$ gases, backpressure of $200 \mathrm{kPa}$, cell temperature of $60{ }^{\circ} \mathrm{C}$ and a scan rate of $10 \mathrm{mV} \mathrm{s}^{-1}$ were used.

\section{Results and discussion}

\subsection{Physical characterisation of catalysts}

The physical characterisation was carried out on the catalyst materials with optimised pyrolysis temperature (i.e., $800^{\circ} \mathrm{C}$ for $\mathrm{Fe} / \mathrm{Co} / \mathrm{IL}-\mathrm{CNF}$ and $900^{\circ} \mathrm{C}$ for $\mathrm{Fe} / \mathrm{Co}-\mathrm{CNF}$ ), according to the ORR activity in $0.1 \mathrm{M} \mathrm{KOH}$ (as shown later in Section 3.2). SEM was employed to study the surface morphology of the prepared catalysts. The SEM micrographs for fibre diameter determination are shown in Fig. S1 (Supplementary material). The diameter of $\mathrm{Fe} / \mathrm{Co} / \mathrm{IL}-\mathrm{CNF}-800-$ based and Fe/Co-CNF-900-based fibres was about 450-650 and 550-750 $\mathrm{nm}$, respectively. The variance in diameter of the electrospun fibre material is a well-known feature $[11,19,20]$. Similar fibre diameters to the present work have been recently obtained with Ni/Co co-doped [14] and Co-doped [22] CNF catalysts. The SEM images with higher magnification are presented in Fig. 1 . In the case of Fe/Co/IL-CNF-800-based materials, the peculiar formations are seen on the CNF surface compared to the Fe/Co-CNF-900-based 
nanofibres. Similar formations have been observed for Fe/Co co-doped CNFs prepared with different TM precursor salts and other electrospinning solution components $[11,20]$. In the study by $\mathrm{Li}$ et al., these formations were found to be related with the formed TM nanoparticles according to the elemental mapping [11]. Herein, these peculiar nanostructures could also correspond to the metal nanoparticles formed on the surface of CNFs. Locally the elongated protrusions can be seen on the surface of the fibres (especially prominent in Fig. 1c). These structures could be formed due to the presence of metal nanoparticles, which during pyrolysis can initiate a formation of nanotube-like structures.
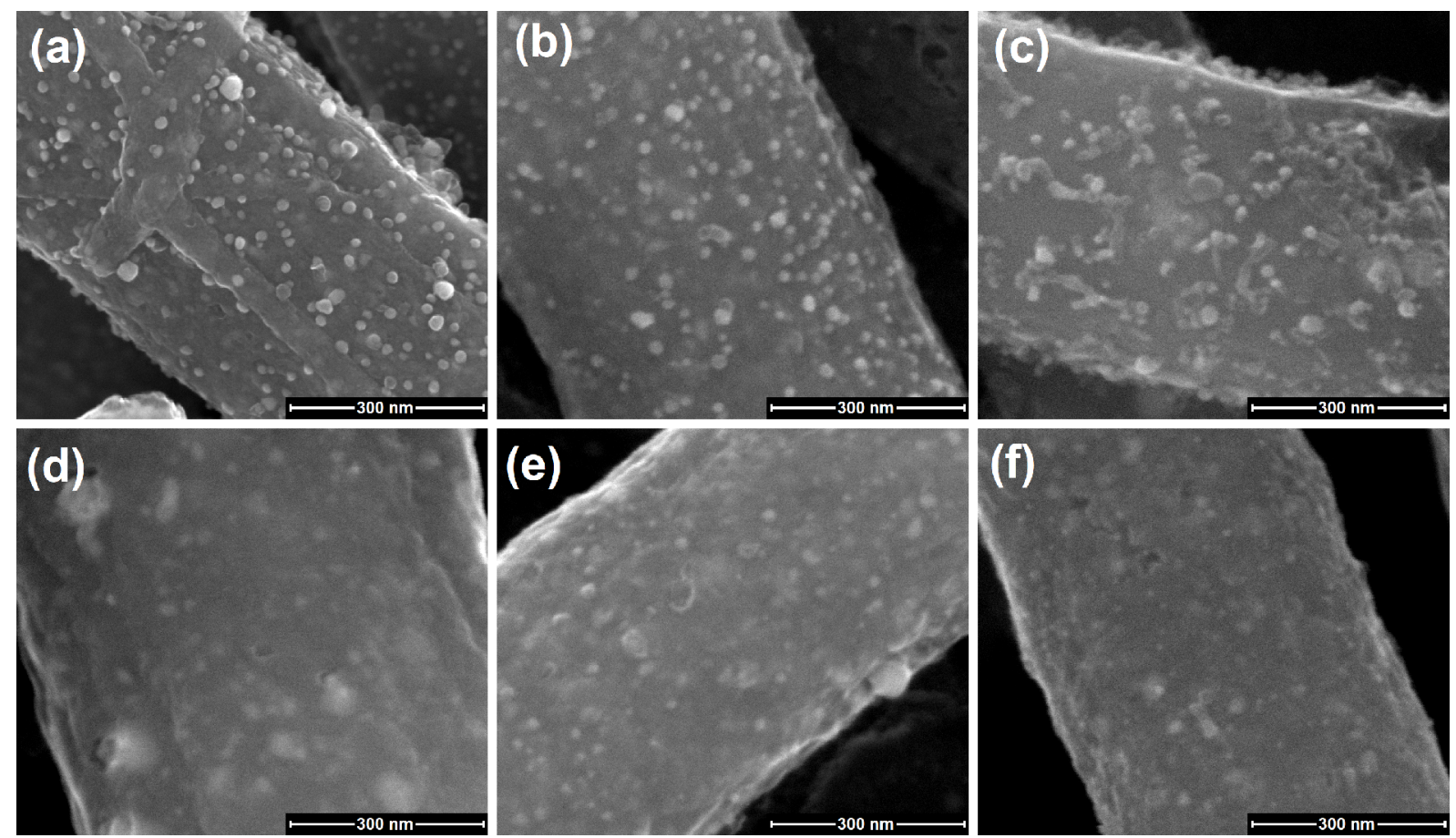

Fig. 1. SEM images of (a) Fe/Co/IL-CNF-800, (b) Fe/Co/IL-CNF-800a, (c) Fe/Co/IL-CNF800b, (d) Fe/Co-CNF-900, (e) Fe/Co-CNF-900a and (f) Fe/Co-CNF-900b catalyst materials.

The SEM-EDX elemental mapping of the Fe/Co/IL-CNF-800-based catalysts in Fig. 2 showed a uniform distribution of $\mathrm{Fe}$ and $\mathrm{Co}$ throughout the material, indicating that the formations observed herein have a rather similar composition with the fibre itself. This is also supported by the presence of formations after the acid treatment procedures (Figs. 1b and c). The bulk elemental composition of the NPMCs was investigated using the EDX analysis and the TM content was also verified via MP-AES (Table 1). For both, Fe/Co/IL-CNF-800 and 
$\mathrm{Fe} / \mathrm{Co}-\mathrm{CNF}-900$, the acid treatment by procedure $1\left(8 \mathrm{~h}\right.$ at $\left.50^{\circ} \mathrm{C}\right)$ has no effect on the TM content, while procedure 2 with higher temperature and longer treatment time $\left(12 \mathrm{~h}\right.$ at $\left.80{ }^{\circ} \mathrm{C}\right)$ has leached out a considerable amount of both $\mathrm{Fe}$ and $\mathrm{Co}$ and introduced a low amount of $\mathrm{S}$. Similarly, the presence of $\mathrm{S}$ has been previously detected in carbon nanotubes after their purification in the $\mathrm{HNO}_{3}+\mathrm{H}_{2} \mathrm{SO}_{4}$ mixture [30].
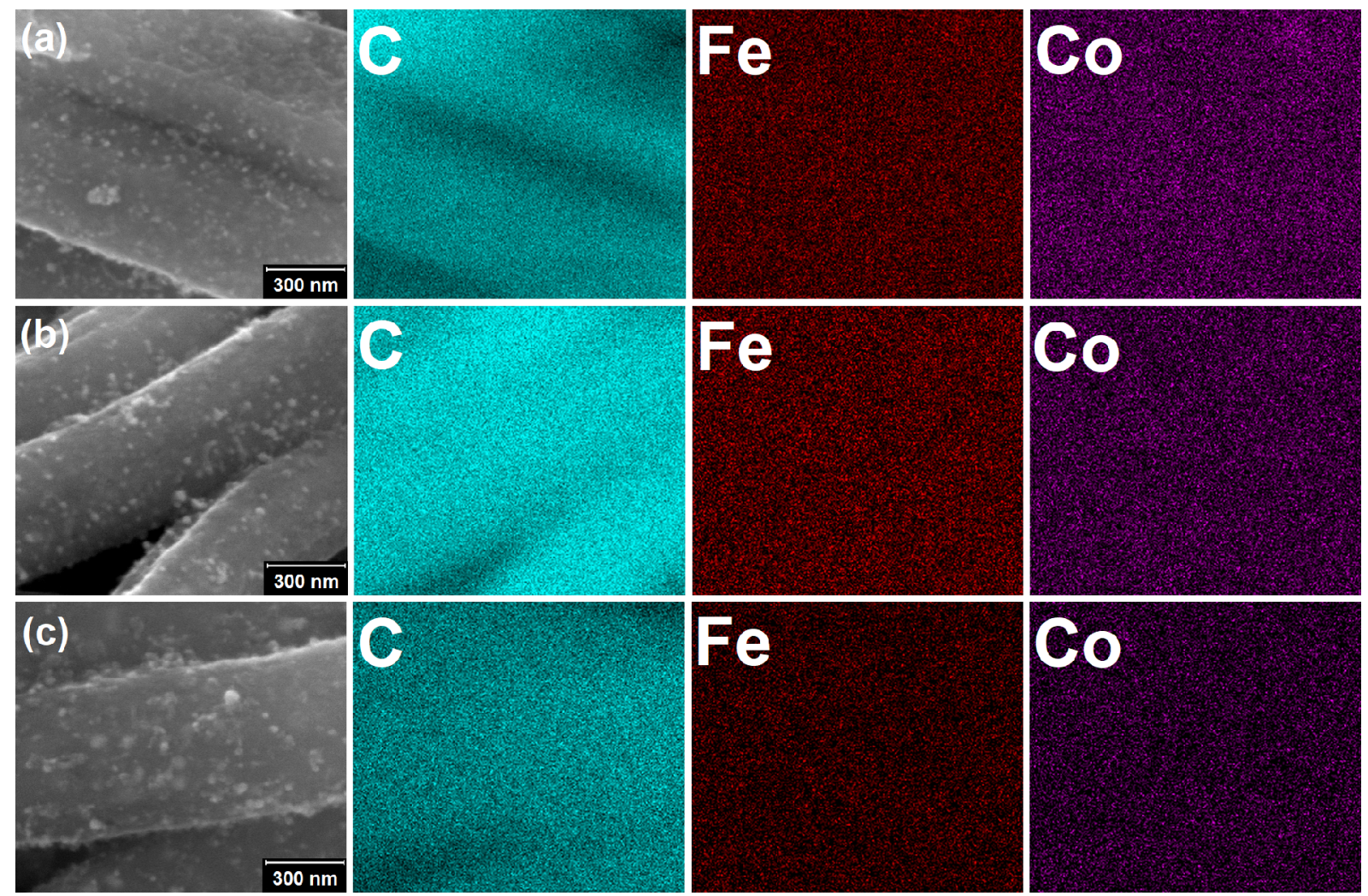

Fig. 2. SEM $\square$ EDX element mapping of the (a) Fe/Co/IL-CNF-800, (b) $\mathrm{Fe} / \mathrm{Co} / \mathrm{IL}-\mathrm{CNF}-800 \mathrm{a}$ and (c) $\mathrm{Fe} / \mathrm{Co} / \mathrm{IL}-\mathrm{CNF}-800 \mathrm{~b}$ catalyst materials.

Raman spectroscopy was employed to study the carbon structure in the NPMCs. As typical to electrospun polymer-based CNF $[13,15,17,31]$, two broad peaks with similar height were observed at $c a .1350$ and $1600 \mathrm{~cm}^{-1}$ for all the samples (Fig. 3). After the deconvolution of the spectra using 4-band fitting, the $I_{\mathrm{D} 1} / I_{\mathrm{G}}$ ratios were calculated for all the catalysts to be higher than 2. This indicates that the $I_{\mathrm{D} 1} / I_{\mathrm{G}}$ ratio is insensitive to the degree of structural disordering of these very defective carbon materials. Although, according to the comparison of D1 and G band width (full width at half maximum, FWHM), the structural disorder 
(amorphous carbon with appreciable $\mathrm{sp}^{3}$ bonding) in the Fe/Co/IL-CNF-800b material is slightly higher than in Fe/Co-CNF-900b. Similarly, $I_{\mathrm{D} 1} / I_{\mathrm{G}}$ ratios higher than 2 have been previously reported by Liu et al. for trimetallic $\mathrm{Co} / \mathrm{Fe} / \mathrm{Ni}$-doped CNF catalysts [19].

Table 1 Elemental composition of different catalyst materials (wt $\%$ ) as determined by EDX analysis. The transition metal content is also determined by MP-AES analysis*.

\begin{tabular}{|l|l|l|l|l|l|l|}
\hline Catalyst material & C & N & $\mathbf{O}$ & $\mathbf{S}$ & $\mathbf{F e}$ & Co \\
\hline Fe/Co/IL-CNF-800 & 72.8 & 5.3 & 3.9 & 0 & $\begin{array}{l}8.3 \\
(7.82+/-0.05)^{*}\end{array}$ & $\begin{array}{l}9.7 \\
(8.13+/-0.04)^{*}\end{array}$ \\
\hline Fe/Co/IL-CNF-800a & 72.3 & 4.5 & 5.3 & 0 & $\begin{array}{l}8.7 \\
(8.33+/-0.07)^{*}\end{array}$ & $\begin{array}{l}9.3 \\
(9.43+/-0.08)^{*}\end{array}$ \\
\hline Fe/Co/IL-CNF-800b & 75.2 & 6.6 & 4.7 & 0.5 & $\begin{array}{l}6.4 \\
(6.39+/-0.12)^{*}\end{array}$ & $\begin{array}{l}6.7 \\
(7.19+/-0.07)^{*}\end{array}$ \\
\hline Fe/Co-CNF-900 & 72.8 & 3.5 & 5.0 & 0 & $\begin{array}{l}8.1 \\
(7.58+/-0.16)^{*}\end{array}$ & $\begin{array}{l}10.6 \\
(9.36+/-0.14)^{*}\end{array}$ \\
\hline $\mathrm{Fe} / \mathrm{Co}-\mathrm{CNF}-900 \mathrm{a}$ & 72.9 & 5.2 & 3.5 & 0 & $\begin{array}{l}8.2 \\
(8.75+/-0.05)^{*}\end{array}$ & $\begin{array}{l}10.2 \\
(10.27+/-0.10)^{*}\end{array}$ \\
\hline $\mathrm{Fe} / \mathrm{Co}-\mathrm{CNF}-900 \mathrm{~b}$ & 80.4 & 4.2 & 3.2 & 0.4 & $\begin{array}{l}5.3 \\
(4.90+/-0.07)^{*}\end{array}$ & $\begin{array}{l}6.4 \\
(6.10+/-0.05)^{*}\end{array}$ \\
\hline
\end{tabular}

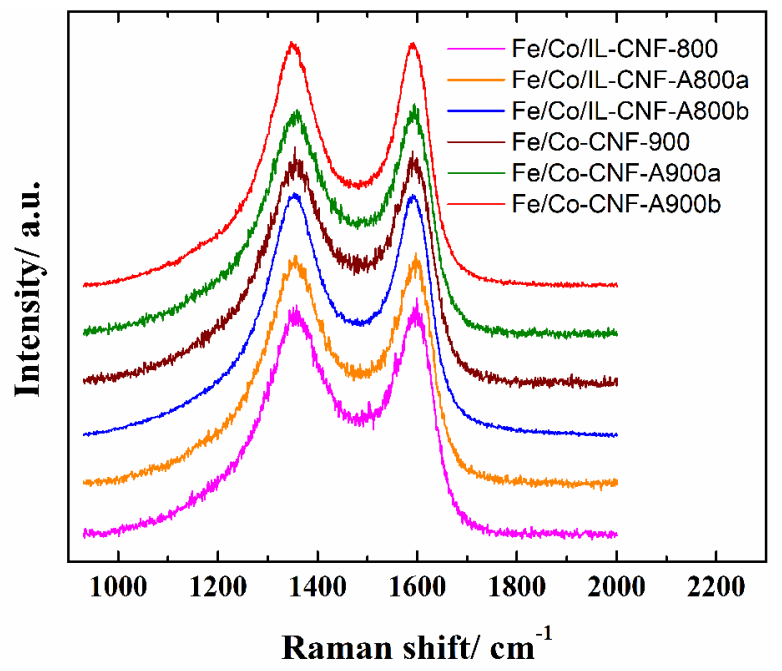

Fig. 3. Raman spectra of Fe/Co/IL-CNF-800 and Fe/Co-CNF-900 catalysts and their acidleached counterparts. In the material designation a and b stand for acid treatment at $50{ }^{\circ} \mathrm{C}$ for $8 \mathrm{~h}$ (procedure 1) and $12 \mathrm{~h}$ at $80^{\circ} \mathrm{C}$ (procedure 2), respectively, followed by second pyrolysis.

To obtain information about the surface composition of Fe/Co/IL-CNF-800 and Fe/Co-CNF900 catalysts and their acid-leached counterparts (treated at $80^{\circ} \mathrm{C}$ for $12 \mathrm{~h}$ ), XPS analysis was performed (Table 2, Figs. 4, S2). The surface of the catalyst materials contains the same elements as the bulk material (Table 1). Although, S was not detected via XPS analysis 
compared to the EDX data, most likely due to the low amount of this element. Similarly to other studies on TM-doped CNF catalysts $[22,31]$, the content of specific elements on the surface is different from the bulk. The detection of Co and Fe on the catalyst surface provides a possibility for the presence of $M-N_{x}$ sites (insets to Figs. 4, S2). The $M-N_{x}$ species were also possibly detected in the deconvoluted N1s spectra (Table 2, Figs. 4, S2). In addition to the high ORR activity, the $M-N_{x}$ sites are also known to be resistant to the acid leaching [32]. The main components in the N1s spectra of all the studied catalysts are pyridinic-N, pyrrolic-N and graphitic-N. While the relative content of pyrrolic-N is around $30 \%$ for all the catalysts, the amount of pyridinic-N is considerably higher in Fe/Co/IL-CNF-800 compared to $\mathrm{Fe} / \mathrm{Co}-$ CNF-900. The latter also applies to their acid-leached counterparts.

Table 2 Elemental composition (at $\%$ ) of different catalyst materials and relative content (\%) of various $\mathrm{N}$ species $\left(\mathrm{N} 1\right.$ - imine, $\mathrm{N} 2-$ pyridinic-N, N3 - metal- $\mathrm{N}_{\mathrm{x}}, \mathrm{N} 4-$ pyrrolic-N, N5 graphitic-N, N6 - bulk N-H, N7 - pyridine-N-oxide) as determined by XPS (Figs. 4 and S2).

\begin{tabular}{|l|c|c|c|c|c|c|c|c|c|c|c|c|}
\hline Catalyst material & $\mathbf{C}$ & $\mathbf{N}$ & $\mathbf{O}$ & $\mathbf{F e}$ & $\mathbf{C o}$ & $\mathbf{N 1}$ & $\mathbf{N 2}$ & $\mathbf{N 3}$ & $\mathbf{N 4}$ & $\mathbf{N 5}$ & $\mathbf{N 6}$ & $\mathbf{N} 7$ \\
\hline $\mathrm{Fe} / \mathrm{Co} / \mathrm{IL}-\mathrm{CNF}-800$ & 87.6 & 6.0 & 5.4 & 0.4 & 0.7 & 2 & 44 & 6 & 28 & 13 & 5 & 3 \\
\hline $\mathrm{Fe} / \mathrm{Co} / \mathrm{IL}-\mathrm{CNF}-800 \mathrm{~b}$ & 87.8 & 5.7 & 5.2 & 0.3 & 0.9 & 2 & 41 & 3 & 32 & 14 & 6 & 3 \\
\hline $\mathrm{Fe} / \mathrm{Co}-\mathrm{CNF}-900$ & 90.3 & 1.7 & 7.6 & 0.1 & 0.3 & 8 & 22 & 12 & 31 & 17 & 7 & 4 \\
\hline $\mathrm{Fe} / \mathrm{Co}-\mathrm{CNF}-900 \mathrm{~b}$ & 91.8 & 5.4 & 2.4 & 0.1 & 0.4 & 4 & 26 & 2 & 32 & 26 & 7 & 3 \\
\hline
\end{tabular}



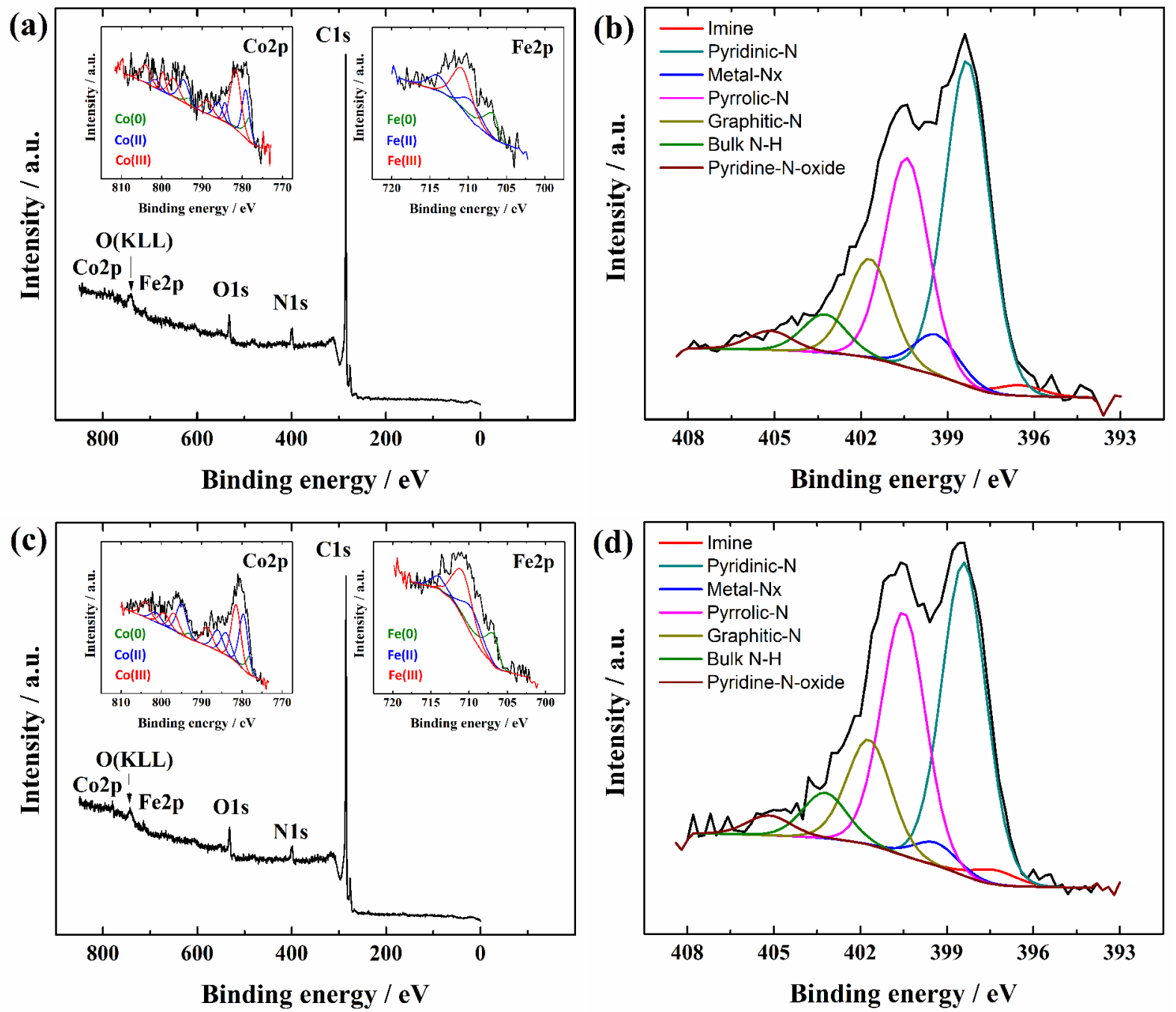

Fig. 4. (a, c) XPS survey spectra and (b, d) deconvoluted high $\square$ resolution N1s spectra of (a, b) $\mathrm{Fe} / \mathrm{Co} / \mathrm{IL}-\mathrm{CNF}-800$, (c, d) Fe/Co/IL-CNF-800b catalyst materials. The insets to a and $\mathrm{c}$ show high $\square$ resolution spectra in the Fe2p, Co2p regions deconvoluted to peaks characteristic to different $\mathrm{Co}$ and $\mathrm{Fe}$ oxidation states.

The crystalline structure of the prepared NPMCs was evaluated by XRD analysis. The XRD patterns of all catalyst materials exhibited a distinctive peak at $c a .25^{\circ}$ as observed in Fig. $5 \mathrm{a}$ for $\mathrm{Fe} / \mathrm{Co} / \mathrm{IL}-\mathrm{CNF}-800 \mathrm{~b}$ and Fe/Co-CNF-900b. The latter peak and the smaller signal at $44^{\circ}$ correspond to the (002) and (101) crystal faces of graphitic carbon, respectively, which is known to be present in the XRD pattern of pyrolysed CNFs [14, 16-19, 31]. The high graphitic carbon content is supported by the presence of $\mathrm{Co}$ and $\mathrm{Fe}$, regarded as the graphitisation catalysts [10]. Another set of XRD peaks at $45^{\circ}, 65^{\circ}$ and $83^{\circ}$, which were present in the diffraction patterns of all catalyst materials, are attributed to the (110), (200) 
and (211) crystal facets of FeCo (1:1) alloy, respectively [11]. In the XRD pattern for $\mathrm{Fe} / \mathrm{Co} / \mathrm{IL}-\mathrm{CNF}-800$ and Fe/Co-CNF-900 catalysts no peaks for Fe or Co oxides were detected (data not shown). After the acid treatment and second pyrolysis, the XRD peaks for $\mathrm{Fe}_{2} \mathrm{O}_{3}$ and $\mathrm{Co}_{3} \mathrm{O}_{4}$ were present, indicating the acid leaching of metallic particles as metal cations but also partial reprecipitation or adsorption of cations on CNF as oxides during the drying step (Fig. 5a). Additionally, the total TM content in both materials (with or without IL additive) has decreased at least by $30 \%$ after the acid treatment at $80{ }^{\circ} \mathrm{C}$ for $12 \mathrm{~h}$ (procedure 2 ) according to the comparison of the obtained XRD data. The TM content did not decrease during the acid treatment by procedure $1\left(8 \mathrm{~h}\right.$ at $\left.50^{\circ} \mathrm{C}\right)$, which is also supported by the EDX data (Table 1). To assess the materials specific surface area (SSA) before and after the acid treatment by procedure $2\left(12 \mathrm{~h}\right.$ at $\left.80^{\circ} \mathrm{C}\right)$, low $\square$ temperature $\mathrm{N}_{2}$ physisorption studies were carried out. The SSA values using the Brunauer $\square$ Emmett $\square$ Teller method ( $\left.S_{\mathrm{BET}}\right)$ were calculated to be 272 and $165 \mathrm{~m}^{2} \mathrm{~g}^{-1}$ for the Fe/Co/IL-CNF-800 and Fe/Co-CNF-900, respectively. The difference indicates that the IL acts as a porogen and can provide higher surface area and higher porosity [31]. The latter can be supported by the higher content of TMs on the material surface in case of $\mathrm{Fe} / \mathrm{Co} / \mathrm{IL}-\mathrm{CNF}-800$ compared to the Fe/Co-CNF-900 (Table 2). After the acid treatment and additional pyrolysis, considerably higher $S_{\mathrm{BET}}$ values were obtained, i.e. 351 and $452 \mathrm{~m}^{2}$ $\mathrm{g}^{-1}$ for $\mathrm{Fe} / \mathrm{Co} / \mathrm{IL}-\mathrm{CNF}-800 \mathrm{~b}$ and $\mathrm{Fe} / \mathrm{Co}-\mathrm{CNF}-900 \mathrm{~b}$, respectively. For comparison, several studies regarding $\mathrm{Co} / \mathrm{Fe}$ co-doped CNF-based catalysts have reported $S_{\mathrm{BET}}$ values similar to $\mathrm{Fe} / \mathrm{Co} / \mathrm{IL}-\mathrm{CNF}-800 \mathrm{~b}$ around $350 \mathrm{~m}^{2} \mathrm{~g}^{-1}[11,12,20]$. The shape of the $\mathrm{N}_{2}$ isotherms on $\mathrm{Fe} / \mathrm{Co} / \mathrm{IL}-\mathrm{CNF}-800 \mathrm{~b}$ and Fe/Co-CNF-900b (inset to Fig. 5b) corresponds to type II with H4 hysteresis according to IUPAC, which is characteristic of micro-mesoporous materials [33]. The pore size distribution (PSD) plots (Fig. 5b) show the presence of three pore size maxima at about $0.8,1.5$ and $3.5 \mathrm{~nm}$, with higher mesopore volumes in case of Fe/Co-CNF-900b. In 
more specific, the amount of micropores according to the $V_{\mu}$ in respect to $V_{\text {tot }}$ was calculated to be $44 \%$ and $36 \%$ for Fe/Co/IL-CNF-800b and Fe/Co-CNF-900b, respectively.
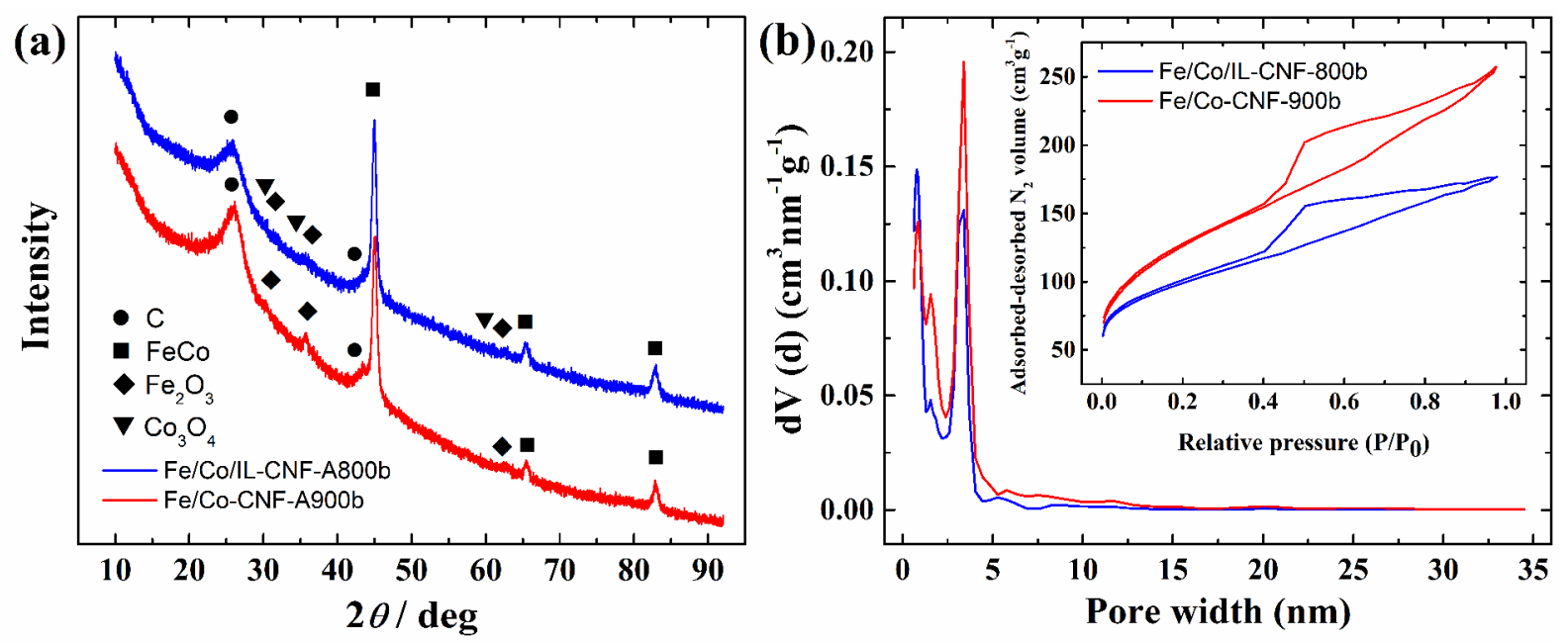

Fig. 5. (a) XRD patterns and (b) PSD for Fe/Co/IL-CNF-800b and Fe/Co-CNF-900b catalyst. The inset to $b$ shows $\mathrm{N}_{2}$ adsorption/desorption isotherms that were used for PSD calculation.

\subsection{Oxygen reduction studies}

Firstly, both electrospun precursors were pyrolysed at 800,900 or $1000^{\circ} \mathrm{C}$, and studied as NPMCs for ORR in $\left.0.1 \mathrm{M} \mathrm{KOH} \mathrm{(Fig.} \mathrm{S3).} \mathrm{The} \mathrm{most} \mathrm{positive} \mathrm{onset} \mathrm{potential} \mathrm{(} E_{\text {onset }}\right)$ and halfwave potential $\left(E_{1 / 2}\right)$ were obtained in the case of Fe/Co/IL-CNF-800 and Fe/Co-CNF-900 for the materials with and without IL additive, respectively. Therefore, these two materials were chosen for further acid-treatment procedures (Fig. 6a, Table 3). According to the $E_{1 / 2}$ value, the procedure $2\left(12 \mathrm{~h}\right.$ at $\left.80^{\circ} \mathrm{C}\right)$ provided a higher ORR activity than acid treatment by procedure $1\left(8 \mathrm{~h}\right.$ at $\left.50{ }^{\circ} \mathrm{C}\right)$. In more specific, the IL-containing CNF-based catalyst Fe/Co/ILCNF-800b showed among the NPMCs studied the most positive $E_{\text {onset }}$ and $E_{1 / 2}$ values of -0.04 and $-0.15 \mathrm{~V}$ vs. SCE, respectively. Although, these are still outperformed by $\mathrm{Pt} / \mathrm{C}$. On the other hand, compared to single TM (Fe or $\mathrm{Co}$ ) containing CNFs in our previous work, the most positive $E_{1 / 2}$ was reported as $-0.19 \mathrm{~V}$ for Co-PAN-A1000 catalyst [22]. This indicates the advantage of Fe and Co co-doping compared to the use of single TM to achieve a higher ORR activity. In other studies with two or three TMs (Fe, Co, Ni, Zn) co-doped CNF-based 
catalysts similar [11] or more negative [13-15] $E_{1 / 2}$ values than Fe/Co/IL-CNF-800b have been reported. In contrast, more positive $E_{1 / 2}$ of $-0.13 \mathrm{~V}$ has been observed by Alegre et al. for $\mathrm{Ni} / \mathrm{Co}$ co-doped CNFs [10]. In a recent work with excellent AEMFC performance (peak power density $\left(P_{\max }\right)$ of $1350 \mathrm{~mW} \mathrm{~cm}^{-2}$ ) using cobalt ferrite nanoparticles supported on Vulcan $\mathrm{XC}-72$, a relatively low current density at $0.8 \mathrm{~V}$ in AEMFC was observed that is in turn consistent with the reported low $E_{1 / 2}$ of $-0.30 \mathrm{~V}$ in $0.1 \mathrm{M} \mathrm{KOH}$ [21].
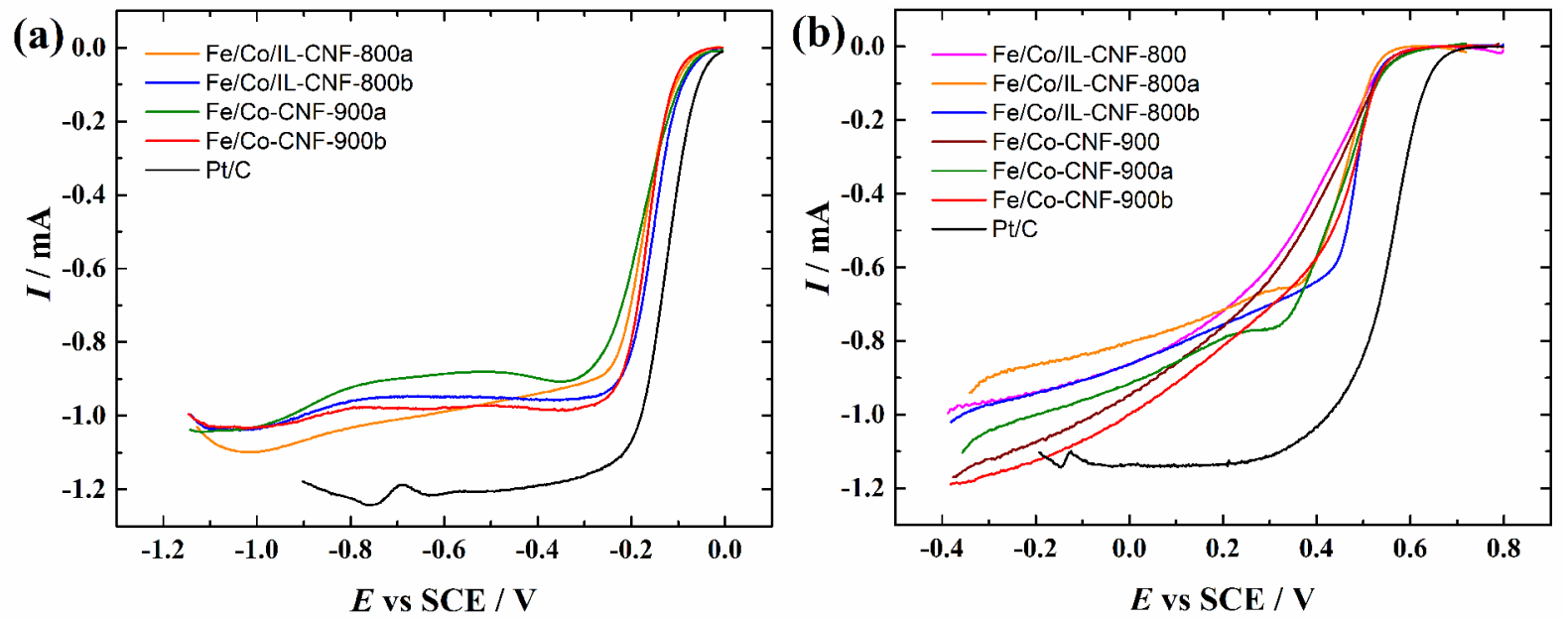

Fig. 6. RDE voltammetry curves for oxygen reduction on $\mathrm{Fe} / \mathrm{Co} / \mathrm{IL}-\mathrm{CNF}-800-$ and $\mathrm{Fe} / \mathrm{Co}-$ CNF-900-based catalysts in $\mathrm{O}_{2}$-saturated (a) $0.1 \mathrm{M} \mathrm{KOH}$ and (b) $0.5 \mathrm{M} \mathrm{H}_{2} \mathrm{SO}_{4}$ at $1900 \mathrm{rpm}, v$ $=10 \mathrm{mV} \mathrm{s}^{-1}$. NPMC loadings of (a) 0.2 and (b) $0.8 \mathrm{mg} \mathrm{cm}^{-2}$ were used. For comparison, the ORR polarisation curve for a commercial $\mathrm{Pt} / \mathrm{C}\left(20 \mu \mathrm{g}_{\mathrm{Pt}} \mathrm{cm}^{-2}\right)$ catalyst is also presented.

As multiple TM containing CNFs have been studied as cathode catalysts in PEMFCs $[16,17]$, then the ORR performance of the prepared NPMCs in $0.5 \mathrm{M} \mathrm{H}_{2} \mathrm{SO}_{4}$ was also explored (Fig. $6 \mathrm{~b}$, Table 3). Similarly to that observed in alkaline media, the $E_{1 / 2}$ value closest to the one of $\mathrm{Pt} / \mathrm{C}\left(E_{1 / 2}=0.56 \mathrm{~V}\right)$ was observed for Fe/Co/IL-CNF-800b $\left(E_{1 / 2}=0.46 \mathrm{~V}\right)$ in $0.5 \mathrm{M} \mathrm{H}_{2} \mathrm{SO}_{4}$. For comparison, in several studies with different TM co-doped CNFs, more positive $E_{1 / 2}$ values have been reported, which are comparable to the one obtained for $\mathrm{Pt} / \mathrm{C}$ herein $[17,19]$. 
Table 3 ORR onset potential ( $\left.E_{\text {onset }}\right)$, ORR half-wave potential $\left(E_{1 / 2}\right)$, potential at OER current density at $10 \mathrm{~mA} \mathrm{~cm}{ }^{-2}\left(E_{2 \mathrm{~mA}}\right)$ and the ORR/OER reversibility $(\Delta E)$ values for different catalyst material coated electrodes. Test solutions: $\mathrm{O}_{2}$-saturated $0.1 \mathrm{M} \mathrm{KOH}$ (a) and $0.5 \mathrm{M}$ $\mathrm{H}_{2} \mathrm{SO}_{4}(\mathrm{~b})$. All the potential values have been obtained from the iR-drop corrected $I-E$ curves.

\begin{tabular}{|c|c|c|c|c|c|c|}
\hline Electrode & $\underset{\mathbf{a}}{E_{\text {onset }}(\mathbf{V})}$ & $E_{1 / 2}(V)^{a}$ & $E_{2 \mathrm{~mA}}(\mathrm{~V})^{\mathrm{a}}$ & $\Delta E(\mathrm{~V})^{\mathrm{a}}$ & $\underset{\text { b }}{E_{\text {onset }}(\mathbf{V})}$ & $E_{1 / 2}(\mathbf{V})^{b}$ \\
\hline $\begin{array}{l}\mathrm{Fe} / \mathrm{Co} / \mathrm{IL}-\mathrm{CNF}- \\
800\end{array}$ & -0.07 & -0.19 & 0.71 & 0.90 & 0.57 & 0.36 \\
\hline $\begin{array}{l}\mathrm{Fe} / \mathrm{Co} / \mathrm{IL}-\mathrm{CNF}- \\
800 \mathrm{a}\end{array}$ & -0.06 & -0.17 & 0.67 & 0.84 & 0.55 & 0.43 \\
\hline $\begin{array}{l}\mathrm{Fe} / \mathrm{Co} / \mathrm{IL}-\mathrm{CNF}- \\
800 \mathrm{~b}\end{array}$ & -0.04 & -0.15 & 0.65 & 0.80 & 0.57 & 0.46 \\
\hline $\mathrm{Fe} / \mathrm{Co}-\mathrm{CNF}-900$ & -0.07 & -0.20 & 0.72 & 0.92 & 0.59 & 0.34 \\
\hline $\mathrm{Fe} / \mathrm{Co}-\mathrm{CNF}-900 \mathrm{a}$ & -0.06 & -0.19 & 0.68 & 0.87 & 0.59 & 0.41 \\
\hline $\mathrm{Fe} / \mathrm{Co}-\mathrm{CNF}-900 \mathrm{~b}$ & -0.07 & -0.17 & 0.63 & 0.80 & 0.57 & 0.40 \\
\hline $\mathrm{Pt} / \mathrm{C}$ & -0.02 & -0.13 & - & - & 0.68 & 0.56 \\
\hline
\end{tabular}

The ORR activity of Fe/Co/IL-CNF-800b and Fe/Co-CNF-900b catalysts was also studied in more detail. The RDE voltammetry curves for ORR obtained in $0.1 \mathrm{M} \mathrm{KOH}$ at different rotation rates and the Koutecky-Levich (K-L) plots derived from these polarisation curves are presented in Fig. 7. According to a comparison of the K-L plots, the diffusion-limited current is obtained at more positive potential values in the case of Fe/Co/IL-CNF-800b catalyst as the extrapolated K-L lines yield zero intercept at higher potential values compared to the ones of Fe/Co-CNF-900b. The electron transfer number $(n)$ was calculated from the slopes of the K-L lines using the K-L equation and parameters taken from our previous work [27]. The obtained $n$ values (insets to Figs $7 \mathrm{~b}, \mathrm{~d}$ ) demonstrated that the ORR proceeds via $4 \mathrm{e}^{-}$pathway for both the studied catalysts, which is promising for the targeted application in AEMFC cathodes. The RDE voltammetry curves at different rotation rates, the corresponding K-L plots and $n$ values recorded in $0.5 \mathrm{M} \mathrm{H}_{2} \mathrm{SO}_{4}$ are presented in Fig. S4. The parameters for $n$ calculation in acid solution were taken from our previous study [34]. In the acidic medium, the diffusionlimited current plateau is reached only for Fe/Co-CNF-900b catalyst from $-0.3 \mathrm{~V}$ vs. SCE 
(Fig. S4d). On the other hand, the $n$ value is closer to 4 at more positive potentials in the case of $\mathrm{Fe} / \mathrm{Co} / \mathrm{IL}-\mathrm{CNF}-800 \mathrm{~b}$ (inset to Fig. S4b).
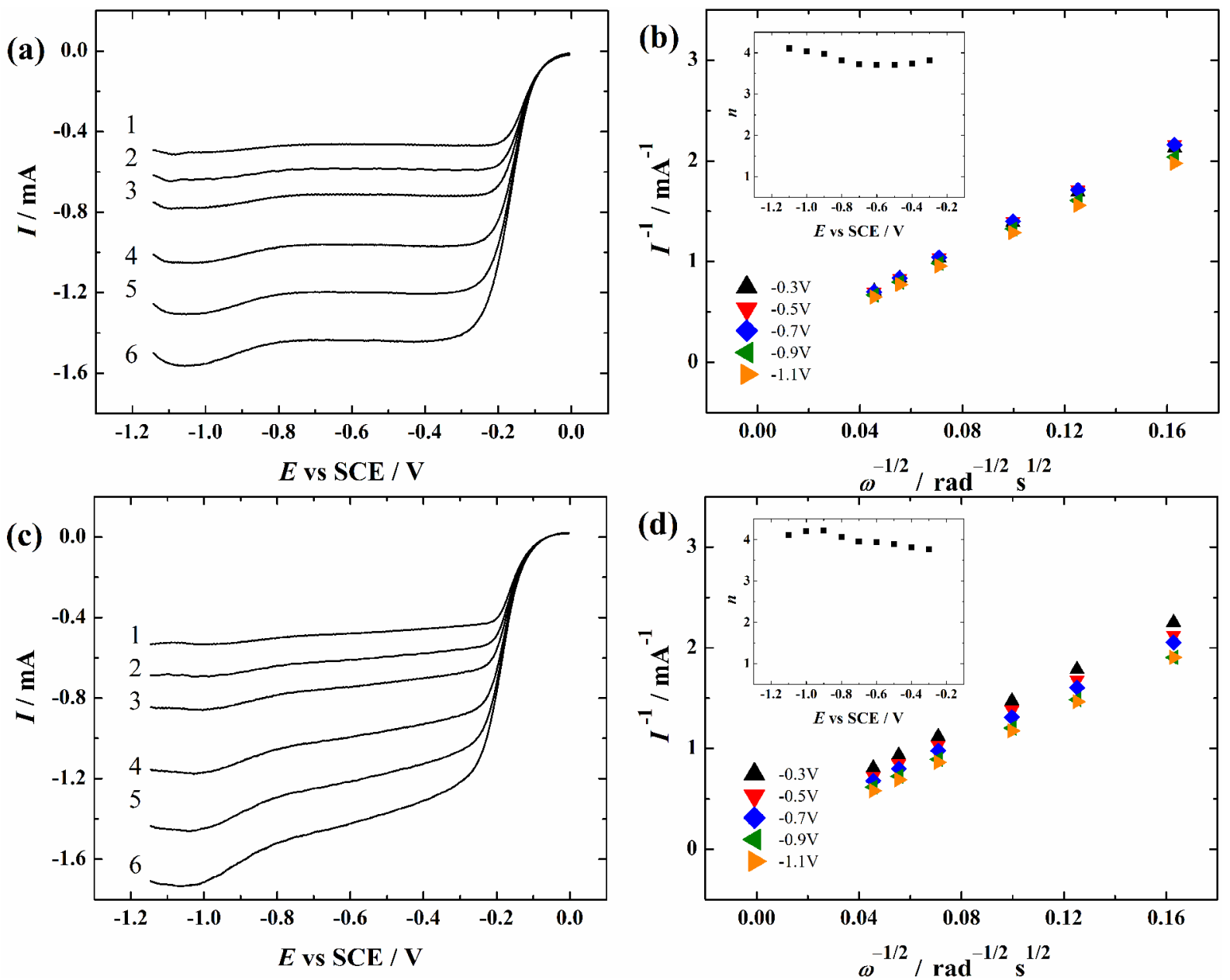

Fig. 7. (a, c) RDE voltammetry curves and (b, d) Koutecky-Levich plots for $\mathrm{O}_{2}$ reduction recorded with $(\mathrm{a}, \mathrm{b}) \mathrm{Fe} / \mathrm{Co} / \mathrm{IL}-\mathrm{CNF}-800 \mathrm{~b}$ and $(\mathrm{c}, \mathrm{d}) \mathrm{Fe} / \mathrm{Co}-\mathrm{CNF}-900 \mathrm{~b}$ coated GC electrodes in $\mathrm{O}_{2} \square$ saturated $0.1 \mathrm{M} \mathrm{KOH}$ at (1) 360, (2) 610, (3) 960, (4) 1900, (5) 3100 and (6) $4600 \mathrm{rpm}$ at $10 \mathrm{mV} \mathrm{s}^{-1}$. NPMC loading: $0.2 \mathrm{mg} \mathrm{cm}^{-2}$. The insets to $(\mathrm{b}, \mathrm{d})$ show the electron transfer number $(n)$ as a function of potential.

As the bifunctionality of the NPMCs to catalyse both OER and ORR reactions is very often evaluated for the development of rechargeable metal-air batteries $[12,13,35,36]$, the OER performance in $0.1 \mathrm{M} \mathrm{KOH}$ was also studied (Fig. S5). The values of potential to achieve the OER current of $2 \mathrm{~mA}\left(E_{2 \mathrm{~mA}}\right)$, which is equal to $10 \mathrm{~mA} \mathrm{~cm}{ }^{-2}$ are presented in Table 3 . The lowest $E_{2 \mathrm{~mA}}$ values were determined as 0.65 and $0.63 \mathrm{~V}$ vs. SCE for Fe/Co/IL-CNF-800b and Fe/Co-CNF-900b, respectively. For comparison, a very similar $E_{2 \mathrm{~mA}}$ value to $\mathrm{Fe} / \mathrm{Co}-\mathrm{CNF}$ $900 \mathrm{~b}$ has been previously reported for Ni/Co co-doped CNFs [10]. For the evaluation of the 
catalyst bifunctionality, the difference of potential $(\Delta E)$ between $E_{1 / 2}(\mathrm{ORR})$ and $E_{2 \mathrm{~mA}}(\mathrm{OER})$ [14] should be calculated (Table 3). Herein, the lowest $\Delta E$ value of $0.80 \mathrm{~V}$ was observed for $\mathrm{Fe} / \mathrm{Co} / \mathrm{IL}-\mathrm{CNF}-800 \mathrm{~b}$ and $\mathrm{Fe} / \mathrm{Co}-\mathrm{CNF}-900 \mathrm{~b}$ electrocatalysts. For comparison, rather close $\Delta E$ values $(0.76-0.79 \mathrm{~V})$ have been reported for several Ni/Co co-doped CNFs $[10,14]$. While, lower $\Delta E$ values $(0.62-0.69 \mathrm{~V})$ have been obtained for $\mathrm{Co} / \mathrm{Fe} / \mathrm{Ni}$ [13] and $\mathrm{Fe} / \mathrm{Co}$ [11] codoped CNF-based NPMCs in $0.1 \mathrm{M} \mathrm{KOH}$. As an exception, in the remarkably more concentrated alkaline solution of $6.0 \mathrm{M} \mathrm{KOH}$, the $\Delta E$ value as low as $0.48 \mathrm{~V}$ has been reported for iron-cobaltite spinel supported CNFs [12]. Regarding the latter study, the use of 6 $\mathrm{M} \mathrm{KOH}$ is more suitable environment when the $\mathrm{ZAB}$ is the intended application.

\subsection{AEMFC testing}

According to the ORR studies in $0.1 \mathrm{M} \mathrm{KOH}$, the Fe/Co/IL-CNF-800b and Fe/Co-CNF-900b catalyst materials were chosen for testing as the NPMCs at the AEMFC cathode (Fig. 8, Table 4). For comparison, the data for commercial $\mathrm{Pt} / \mathrm{C}$ catalyst are also presented. The $P_{\max }$ values show that the IL-containing nanofibre-based Fe/Co/IL-CNF-800b outperforms the IL-free Fe/Co-CNF-900b. Moreover, the $P_{\max }$ of Fe/Co/IL-CNF-800b itself makes up ca $78 \%$ of the $P_{\max }$ obtained with commercial $\mathrm{Pt} / \mathrm{C}$. This shows the superiority of $\mathrm{Pt} / \mathrm{C}$ in an $\mathrm{AEMFC}$ in agreement with the RDE results obtained in $0.1 \mathrm{M} \mathrm{KOH} \mathrm{(Fig.} \mathrm{6a).} \mathrm{Although,} \mathrm{the} P_{\max }$ is often reached at the cell voltages at which the practical use is hindered due to the heat rejection. Therefore, a comparison at a higher cell voltage (e.g. $0.65 \mathrm{~V}, P_{0.65 \mathrm{~V}}$ in Table 4$)$ has been proposed for possible real-life applications [37]. Using the $P_{0.65 \mathrm{~V}}$ values for comparison, a difference between Fe/Co/IL-CNF-800b and $\mathrm{Pt} / \mathrm{C}$ is reduced from $22 \%\left(P_{\max }\right)$ to $11 \%$ $\left(P_{0.65 \mathrm{~V})}\right.$.

It is complicated to compare the obtained results with the data from the literature as very different operating conditions and materials have been used for AEMFC testing [37, 38]. Furthermore, there is no prior information available about the AEMFC performance with 
similar catalysts based on multiple TM co-doped electrospun CNFs. Therefore, the selection of results for comparison from other studies has been extended to include several TM codoped carbon-based catalyst materials of different origin (Table 4). As an exception, only Fedoped commercial NPMC material from our previous work $(\mathrm{Fe}-\mathrm{N}-\mathrm{C})$ has been included as the AEMFC testing has been carried out in similar conditions [39]. The Fe-N-C catalyst, which was prepared using VariPore ${ }^{\mathrm{TM}}$ method by Pajarito Powder, LLC, outperformed both NPMCs prepared herein according to both, $P_{\max }$ and $P_{0.65 \mathrm{~V}}$, values [39]. Among the selection of several TM co-doped materials presented in Table 4, the Fe/Co/IL-CNF-800b outperforms several catalyst materials that have been studied in AEMFC conditions with cell testing performed using the commercial Fumatech or Tokuyama AEMs with only $\mathrm{Pt} / \mathrm{C}$ at the anode. In addition to the ORR activity, at least as important role in the AEMFC performance is played by the effective integration of NPMC with the specific GDLs and membrane [40, 41]. Also, the high thickness of the NPMC catalyst layer at the cathode and water management issues (e.g. flooding or drying) have a great influence on the overall fuel cell performance [42, 43]. Considering these aspects together with different GDL material and gas flow rates can provide a possible explanation for the high $P_{\max }$ of $415 \mathrm{~mW} \mathrm{~cm}^{-2}$ obtained with FeCoNC-at catalyst in an earlier investigation, where otherwise similar conditions to the present study were used [44]. Also, more than two times higher $P_{\max }$ of FeCoNC-at compared to the $\mathrm{Fe} / \mathrm{Co} / \mathrm{IL}-\mathrm{CNF}-800 \mathrm{~b}$ could not be solely caused by the catalysts ORR activity as in the kinetically controlled region remarkably closer current density values at $0.85 \mathrm{~V}\left(J_{0.85 \mathrm{~V}}\right)$ around $60 \mathrm{~mA} \mathrm{~cm}{ }^{-2}$ were observed for both catalysts. Furthermore, more negative $E_{1 / 2}$ value was observed in the case of FeCoNC-at $(-0.18 \mathrm{~V})$ compared to Fe/Co/IL-CNF-800b $(-0.15 \mathrm{~V})$ during the RDE experiments in $0.1 \mathrm{M} \mathrm{KOH}$ [44]. In Table 4, the NPMCs showing higher $P_{\max }$ values than FeCoNC-at have all been obtained with laboratory AEMs that are not commercially available. Among the selected catalysts, the highest AEMFC performance with 
$P_{\max }$ of $1350 \mathrm{~mW} \mathrm{~cm}{ }^{-2}$ has been obtained with cobalt ferrite nanoparticles supported on Vulcan carbon XC-72 (CF-VC), although, its $E_{1 / 2}$ value measured in RDE experiments in 0.1 $\mathrm{M} \mathrm{KOH}$ was moderate, at $-0.30 \mathrm{~V}[21]$. This observation confirms the critical importance of other aspects in addition to the ORR kinetic activity of a cathode, in order to achieve a high AEMFC performance.

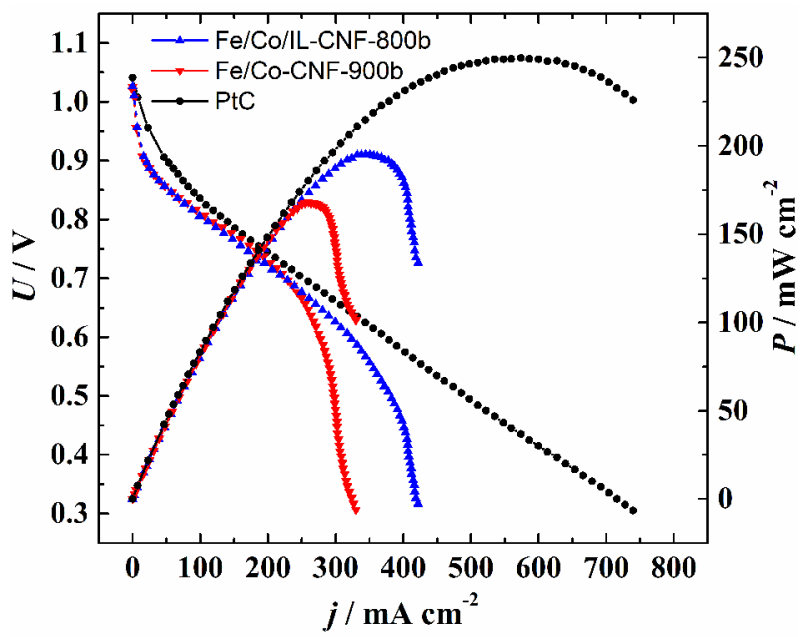

Fig. 8. Power density and polarisation curves for $\mathrm{H}_{2} / \mathrm{O}_{2}$ single $\square$ cell AEMFC with the HMT $\square$ PMBI anion exchange membrane and Fe/Co/IL-CNF-800b, Fe/Co-CNF-900b or Pt/C $\left(0.4 \mathrm{mgt}_{\mathrm{Pt}} \mathrm{cm}^{-2}\right)$ as a cathode catalyst. NPMC loading: $2 \mathrm{mg} \mathrm{cm}^{-2}$. Pt-Ru/C $\left(0.6 \mathrm{mg}_{\mathrm{Pt} \square \mathrm{Ru}} \mathrm{cm}^{-2}\right)$ was used as the anode catalyst. $\mathrm{T}=60^{\circ} \mathrm{C}$.

The observed ORR activity of the NPMC materials prepared in this work should be attributed to their specific composition and architecture. Firstly, the unique fibrous CNF structure with high SSA can provide a large amount of ORR-active sites [6, 27]. The studied NPMCs present a hierarchical porosity, with both micro- and mesopores (Fig. 5b). The micropores are considered necessary to reach high density of $M-N_{x}$ sites $[45,46]$, while the mesopores can promote faster mass transfer $[6,16]$. The presence of high number of ORR-active sites was also supported by Raman spectroscopy, which showed a very defective carbon structure indicated by the bonding of different species through $\mathrm{sp}^{3}$ carbon. The XRD patterns showed the formation of FeCo alloy, which could indicate to the co-existence of FeCo alloy and $\mathrm{Fe} / \mathrm{Co}-\mathrm{N}_{\mathrm{x}}$ active sites that can promote the electrocatalytic activity towards the ORR [11]. The presence of $\mathrm{M}-\mathrm{N}_{\mathrm{x}}$ sites was supported by XPS analyses in the N1s, Co2p and Fe2p regions 
(Table 2). In addition to the $\mathrm{M}-\mathrm{N}_{\mathrm{x}}$ sites, the pyridinic-N, pyrrolic-N and graphitic-N species were also observed in the N1s spectra. Both, pyridinic-N and graphitic-N are generally recognised to contribute to the high ORR activity of CNFs [6, 12, 47-49]. In more specific, the pyridinic-N has been found to improve the ORR onset potential [16], while the graphitic$\mathrm{N}$ provides higher ORR current density through increased electrical conductivity $[14,31]$. In several studies $[6,27,50]$, the pyrrolic- $\mathrm{N}$ has been also regarded beneficial for ORR as it could provide higher charge mobility and better donor-acceptor properties than other doped $\mathrm{N}$ species [51].

Table 4. Comparison of AEMFC performances using different TM co-doped electrocatalysts in the literature. As an exception, the Fe-N-C is only doped with Fe.

\begin{tabular}{|c|c|c|c|c|c|c|c|c|}
\hline $\begin{array}{l}\text { Cathode } \\
\text { catalyst }\end{array}$ & $\begin{array}{l}P_{\max } \\
(\mathrm{mW} \\
\left.\mathrm{cm}^{-2}\right)\end{array}$ & $\begin{array}{l}P_{0.65 \mathrm{~V}} \\
(\mathrm{~mW} \\
\left.\mathrm{cm}^{-2}\right)\end{array}$ & $\begin{array}{c}J_{0.85 \mathrm{~V}}(\mathrm{~mA} \\
\left.\mathrm{cm}^{-2}\right)\end{array}$ & $\begin{array}{c}\text { Cathode } \\
\text { loading } \\
\left(\mathrm{mg} \mathrm{cm}^{-2}\right)\end{array}$ & \begin{tabular}{|c} 
Anode \\
loading \\
$(\mathrm{mg}$ \\
$\left.\mathrm{cm}^{-2}\right)$
\end{tabular} & $\begin{array}{c}\mathrm{T} \\
\left({ }^{\circ} \mathrm{C}\right)\end{array}$ & Membrane & Ref. \\
\hline $\begin{array}{l}\mathrm{Fe} / \mathrm{Co} / \mathrm{IL}- \\
\mathrm{CNF}-800 \mathrm{~b}\end{array}$ & 195 & 179 & 56 & 2 & $0.6 \mathrm{Pt}-\mathrm{Ru}$ & 60 & HMT-PMBI & $\begin{array}{l}\text { This } \\
\text { work }\end{array}$ \\
\hline $\begin{array}{c}\mathrm{Fe} / \mathrm{Co}-\mathrm{CNF}- \\
900 \mathrm{~b}\end{array}$ & 168 & 168 & 53 & 2 & $0.6 \mathrm{Pt}-\mathrm{Ru}$ & 60 & HMT-PMBI & $\begin{array}{l}\text { This } \\
\text { work }\end{array}$ \\
\hline $\mathrm{Pt} / \mathrm{C}$ & 250 & 201 & 87 & $0.4 \mathrm{Pt}$ & $0.6 \mathrm{Pt}-\mathrm{Ru}$ & 60 & HMT-PMBI & $\begin{array}{l}\text { This } \\
\text { work }\end{array}$ \\
\hline Fe-N-C & 220 & 217 & 133 & 2 & $0.6 \mathrm{Pt}-\mathrm{Ru}$ & 60 & HMT-PMBI & [39] \\
\hline $\mathrm{NiCo} / \mathrm{NCNTs}$ & 65 & $43 *$ & $14^{*}$ & 4 & $0.12 \mathrm{Pt}$ & 50 & $\begin{array}{l}\text { Fumatech FAA-3- } \\
50\end{array}$ & {$[52]$} \\
\hline $\mathrm{Co}-\mathrm{Fe}_{3} \mathrm{O}_{4} / \mathrm{C}$ & 114 & $69 *$ & 0 & 0.8 & $0.8 \mathrm{Pt}$ & 60 & Fumatech FAA-3 & [53] \\
\hline $\begin{array}{c}\mathrm{CoFeN} / \mathrm{C}- \\
\text { HLH }\end{array}$ & 177 & $146^{*}$ & $22 *$ & 4 & $0.4 \mathrm{Pt}$ & 50 & Tokuyama A201 & {$[54]$} \\
\hline FeCoNC-at & 415 & 350 & 63 & 2 & $0.6 \mathrm{Pt}-\mathrm{Ru}$ & 60 & HMT-PMBI & {$[44]$} \\
\hline $\mathrm{Fe}-\mathrm{Co}-\mathrm{N}-\mathrm{C}$ & 420 & $181^{*}$ & - & 1 & $0.7 \mathrm{Pt}-\mathrm{Ru}$ & 60 & $\begin{array}{l}\text { LDPE-based } \\
\text { AEM }\end{array}$ & {$[55]$} \\
\hline $\begin{array}{c}\alpha- \\
\mathrm{Mn}_{2} \mathrm{O}_{3} / \mathrm{Fe}_{0.5^{-}} \\
\mathrm{NH}_{3}\end{array}$ & 980 & $629 *$ & $154^{*}$ & 1.5 & $0.9 \mathrm{Pt}-\mathrm{Ru}$ & 60 & ETFE-based AEM & {$[56]$} \\
\hline $\begin{array}{c}\text { CoFe-N- } \\
\text { CDC/CNT }\end{array}$ & 1120 & 815 & 24 & 0.01 metal & $0.7 \mathrm{Pt}-\mathrm{Ru}$ & 60 & ETFE-based AEM & [57] \\
\hline $\mathrm{MnCo}_{2} \mathrm{O}_{4} / \mathrm{C}$ & 1200 & $775^{*}$ & $71^{*}$ & $\begin{array}{c}0.8 \text { metal } \\
\text { oxides }\end{array}$ & $0.4 \mathrm{Pt}-\mathrm{Ru}$ & 80 & QAPPT & [58] \\
\hline CF-VC & 1350 & $651^{*}$ & $28^{*}$ & 2.4 & $0.7 \mathrm{Pt}-\mathrm{Ru}$ & 70 & $\begin{array}{c}\text { polyethylene- } \\
\text { based AEM }\end{array}$ & [21] \\
\hline
\end{tabular}

*The value is determined from the polarisation curve. 
The higher AEMFC performance obtained with Fe/Co/IL-CNF-800b compared to Fe/CoCNF-900b could be also explained in terms of the porous structure and site distribution in the fibre-based electrodes. Firstly, the IL was found to cause the appearance of peculiar formations on the nanofibre surface (Fig. 1) providing an easily accessible surface area compared to the IL-free fibres. Despite the $S_{\mathrm{BET}}$ being higher in the case of Fe/Co-CNF-900b catalyst, the amount of surface pores and active sites in Fe/Co/IL-CNF-800b could be higher due to these structures. The pores on the nanofibre surface are more easily accessible to the $\mathrm{O}_{2}$ molecules compared to the inner porosity of CNF. Additionally, the physical characterisation showed a higher amount of micropores (Fig. 5b) and structural disorder (Fig. 3) in the case of $\mathrm{Fe} / \mathrm{Co} / \mathrm{IL}-\mathrm{CNF}-800 \mathrm{~b}$ catalyst. The more positive ORR $E_{\text {onset }}$ value obtained for $\mathrm{Fe} / \mathrm{Co} / \mathrm{IL}-$ CNF-800b compared to the Fe/Co-CNF-900b in $0.1 \mathrm{M} \mathrm{KOH} \mathrm{(Table} \mathrm{3)} \mathrm{could} \mathrm{be} \mathrm{due} \mathrm{to} \mathrm{the}$ higher relative content of pyridinic-N (Table 2) [16].

In summary, we propose for the first time $\mathrm{Co}$ and $\mathrm{Fe}$ co-doped electrospun CNF-based cathode catalysts for AEMFC application. The power density obtained with Fe/Co/IL-CNF$800 \mathrm{~b}$ catalyst at $-0.65 \mathrm{~V}$ was $89 \%$ of the power density obtained with commercial Pt/C.

\section{Conclusions}

In the present work, the NPMC materials were prepared via pyrolysis of Co and Fe co-doped electrospun CNFs with and without an IL additive as porogen. The low $\square$ temperature $\mathrm{N}_{2}$ physisorption studies indicated the formation of micro-mesoporous nanofibre structure and the XPS experiments showed the presence of different $\mathrm{N}$ and $\mathrm{M}-\mathrm{N}_{\mathrm{x}}$ species, which are all known to be beneficial for high ORR activity. Raman spectroscopy showed very defective carbon structure and the XRD patterns indicated the presence of a FeCo alloy, which can also boost the ORR activity. The IL-containing nanofibre-based Fe/Co/IL-CNF-800b material possess the highest activity towards the ORR as demonstrated by RDE studies in both acidic 
and alkaline media. The OER studies revealed that the ORR/OER reversibility $(\Delta E)$ of such catalyst was $0.80 \mathrm{~V}$. Very similar $\Delta E$ value was obtained for the most active IL-free fibrebased NPMC (Fe/Co-CNF-900b). The Fe/Co/IL-CNF-800b and Fe/Co-CNF-900b were studied as a cathode catalyst in an AEMFC and the $P_{\max }$ values of 168 and $195 \mathrm{~mW} \mathrm{~cm}{ }^{-2}$, respectively, were obtained. The $P_{\max }$ value of the Fe/Co/IL-CNF-800b was $78 \%$ of that obtained for $\mathrm{Pt} / \mathrm{C}$ catalyst.

\section{Acknowledgements}

The present study was financially supported by the Estonian Research Council (grants PRG723 and PRG4) and the M-ERA.Net project "C-MOF.cell" (SLTKT20445). This research was also supported by the EU through the European Regional Development Fund (TK141 "Advanced materials and high-technology devices for energy recuperation systems", TK134 "Emerging orders in quantum and nanomaterials" and TK143 "Molecular cell engineering"). SC acknowledges IUF for financial support.

\section{References}

[1] Zhou XX, Wang Y, Gong CC, Liu B, Wei G. Production, structural design, functional control, and broad applications of carbon nanofiber-based nanomaterials: A comprehensive review. Chem. Eng. J. 2020;402:26.

[2] Barhoum A, Pal K, Rahier H, Uludag H, Kim IS, Bechelany M. Nanofibers as newgeneration materials: From spinning and nano-spinning fabrication techniques to emerging applications. Appl. Mater. Today 2019;17:1-35.

[3] Lei YP, Wang QC, Peng SJ, Ramakrishna S, Zhang D, Zhou KC. Electrospun Inorganic Nanofibers for Oxygen Electrocatalysis: Design, Fabrication, and Progress. Adv. Energy Mater. 2020;10:29.

[4] Liu Q, Zhu JH, Zhang LW, Qiu YJ. et al. Recent advances in energy materials by electrospinning. Renew. Sustain. Energy Rev. 2018;81:1825-58.

[5] Wang CH, Kaneti YV, Bando Y, Lin JJ, Liu C, Li JS, et al. Metal-organic frameworkderived one-dimensional porous or hollow carbon-based nanofibers for energy storage and conversion. Mater. Horiz. 2018;5:394-407.

[6] Xu ZQ, Zhao HT, Liang J, Wang Y, Li TS, Luo YS, et al. Noble-metal-free electrospun nanomaterials as electrocatalysts for oxygen reduction reaction. Mater. Today Phys. 2020;15:16. 
[7] Rauf M, Wang JW, Zhang PX, Iqbal W, Qu JL, Li YL. Non-precious nanostructured materials by electrospinning and their applications for oxygen reduction in polymer electrolyte membrane fuel cells. J. Power Sources 2018;408:17-27.

[8] Cavaliere S, Subianto S, Savych I, Jones DJ, Roziere J. Electrospinning: designed architectures for energy conversion and storage devices. Energy Environ. Sci. 2011;4:4761-85.

[9] Sarapuu A, Kibena-Põldsepp E, Borghei M, Tammeveski K. Electrocatalysis of oxygen reduction on heteroatom-doped nanocarbons and transition metal-nitrogen-carbon catalysts for alkaline membrane fuel cells. J. Mater. Chem. A 2018;6:776-804.

[10] Alegre C, Modica E, Di Blasi A, Di Blasi O, Busacca C, Ferraro M, et al. NiCo-loaded carbon nanofibers obtained by electrospinning: Bifunctional behavior as air electrodes. Renew. Energy 2018;125:250-9.

[11] Li CL, Wu MC, Liu R. High-performance bifunctional oxygen electrocatalysts for zincair batteries over mesoporous $\mathrm{Fe} / \mathrm{Co}-\mathrm{N}-\mathrm{C}$ nanofibers with embedding $\mathrm{FeCo}$ alloy nanoparticles. Appl. Catal. B 2019;244:150-8.

[12] Alegre C, Busacca C, Di Blasi A, Di Blasi O, Arico AS, Antonucci V, et al. Toward more efficient and stable bifunctional electrocatalysts for oxygen electrodes using $\mathrm{FeCo}_{2} \mathrm{O}_{4} /$ carbon nanofiber prepared by electrospinning. Mater. Today Energy 2020;18:9.

[13] Cao F, Yang X, Shen C, Li X, Wang JM, Qin GW, et al. Electrospinning synthesis of transition metal alloy nanoparticles encapsulated in nitrogen-doped carbon layers as an advanced bifunctional oxygen electrode. J. Mater. Chem. A 2020;8:7245-52.

[14] Feng C, Guo Y, Xie YH, Cao XL, Li S, Zhang LG, et al. Bamboo-like nitrogen-doped porous carbon nanofibers encapsulated nickel-cobalt alloy nanoparticles composite material derived from the electrospun fiber of a bimetal-organic framework as efficient bifunctional oxygen electrocatalysts. Nanoscale 2020;12:5942-52.

[15] Liu C, Wang J, Li JS, Liu JZ, Wang CH, Sun XY, et al. Electrospun ZIF-based hierarchical carbon fiber as an efficient electrocatalyst for the oxygen reduction reaction. J. Mater. Chem. A 2017;5:1211-20.

[16] Zang J, Wang FT, Cheng QQ, Wang GL, Ma LS, Chen C, et al. Cobalt/zinc dual-sites coordinated with nitrogen in nanofibers enabling efficient and durable oxygen reduction reaction in acidic fuel cells. J. Mater. Chem. A 2020;8:3686-91.

[17] He YH, Guo H, Hwang S, Yang XX, He ZZ, Braaten J, et al. Single Cobalt Sites Dispersed in Hierarchically Porous Nanofiber Networks for Durable and High-Power PGM-Free Cathodes in Fuel Cells. Adv. Mater. 2020;32:14.

[18] Deng Z, Yi Q, Li G, Chen Y, Yang X, Nie H. NiCo-doped C-N nano-composites for cathodic catalysts of $Z n$-air batteries in neutral media. Electrochim. Acta 2018;279:1-9.

[19] Liu Q, Cao S, Fu Y, Guo Y, Qiu Y. Trimetallic FeCoNi-N/C nanofibers with high electrocatalytic activity for oxygen reduction reaction in sulfuric acid solution. J. Electroanal. Chem. 2018;813:52-7.

[20] Uhm S, Jeong B, Lee J. A facile route for preparation of non-noble CNF cathode catalysts in alkaline ethanol fuel cells. Electrochim. Acta 2011;56:9186-90.

[21] Peng X, Kashyap V, Ng B, Kurungot S, Wang LQ, Varcoe JR, et al. High-Performing PGM-Free AEMFC Cathodes from Carbon-Supported Cobalt Ferrite Nanoparticles. Catalysts 2019;9:12.

[22] Mooste M, Kibena-Põldsepp E, Vassiljeva V, Kikas A, Käärik M, Kozlova J, et al. Electrospun Polyacrylonitrile-Derived Co or Fe Containing Nanofibre Catalysts for Oxygen Reduction Reaction at the Alkaline Membrane Fuel Cell Cathode. ChemCatChem 2020;12:4568-81.

[23] Mooste M, Kibena-Põldsepp E, Matisen L, Merisalu M, Kook M, Kisand V, et al. Oxygen Reduction on Catalysts Prepared by Pyrolysis of Electrospun Styrene- 
Acrylonitrile Copolymer and Multi-walled Carbon Nanotube Composite Fibres. Catal. Letters 2018;148:1815-26.

[24] Sadezky A, Muckenhuber H, Grothe H, Niessner R, Poschl U. Raman micro spectroscopy of soot and related carbonaceous materials: Spectral analysis and structural information. Carbon 2005;43:1731-42.

[25] Brunauer S, Emmett PH, Teller E. Adsorption of Gases in Multimolecular Layers. J. Am. Chem. Soc. 1938;60:309-19.

[26] Mooste M, Tkesheliadze T, Kozlova J, Kikas A, Kisand V, Treshchalov A, et al. Transition metal phthalocyanine-modified shungite-based cathode catalysts for alkaline membrane fuel cell. Int. J. Hydrog. Energy 2021;46:4365-77.

[27] Mooste M, Kibena-Põldsepp E, Vassiljeva V, Merisalu M, Kook M, Treshchalov A, et al. Electrocatalysts for oxygen reduction reaction based on electrospun polyacrylonitrile, styrene-acrylonitrile copolymer and carbon nanotube composite fibres. J. Mater. Sci. 2019;54:11618-34.

[28] Ping KF, Braschinsky A, Alam M, Bhadoria R, Mikli V, Mere A, et al. Fused Hybrid Linkers for Metal-Organic Framework-Derived Bifunctional Oxygen Electrocatalysts. ACS Appl. Energy Mater. 2020;3:152-7.

[29] Wright AG, Fan JT, Britton B, Weissbach T, Lee HF, Kitching EA, et al. Hexamethyl-pterphenyl poly(benzimidazolium): a universal hydroxide-conducting polymer for energy conversion devices. Energy Environ. Sci. 2016;9:2130-42.

[30] Kruusenberg I, Alexeyeva N, Tammeveski K, Kozlova J, Matisen L, Sammelselg V, et al. Effect of purification of carbon nanotubes on their electrocatalytic properties for oxygen reduction in acid solution. Carbon 2011;49:4031-9.

[31] Wang CC, Li Q, Guo JN, Ren YY, Zhang JW, Yan F. Metal-containing Ionic Liquid/Polyacrylonitrile-derived Carbon Nanofibers for Oxygen Reduction Reaction and Flexible Zn-Air Battery. Chem. Asian J. 2019;14:2008-17.

[32] Buan MEM, Cognigni A, Walmsley JC, Muthuswamy N, Ronning M. Active sites for the oxygen reduction reaction in nitrogen-doped carbon nanofibers. Catal. Today 2020;357:248-58.

[33] Thommes M, Kaneko K, Neimark AV, Olivier JP, Rodriguez-Reinoso F, Rouquerol J, et al. Physisorption of gases, with special reference to the evaluation of surface area and pore size distribution (IUPAC Technical Report). Pure Appl. Chem. 2015;87:1051-69.

[34] Canuto de Almeida e Silva T, Mooste M, Kibena-Põldsepp E, Matisen L, Merisalu M, Kook $\mathrm{M}$, et al. Polymer-derived $\mathrm{Co} / \mathrm{Ni}-\mathrm{SiOC}(\mathrm{N})$ ceramic electrocatalysts for oxygen reduction reaction in fuel cells. Catal. Sci. Technol. 2019;9:854-66.

[35] Kisand K, Sarapuu A, Kikas A, Kisand V, Rähn M, Treshchalov A, et al. Bifunctional multi-metallic nitrogen-doped nanocarbon catalysts derived from 5-methylresorcinol. Electrochem. commun. 2021;124:106932.

[36] Kazimova N, Ping K, Alam M, Danilson M, Merisalu M, Aruväli J, et al. Shungitederived graphene as a carbon support for bifunctional oxygen electrocatalysts. J. Catal. 2021;395:178-87.

[37] Ramaswamy N, Mukerjee S. Alkaline Anion-Exchange Membrane Fuel Cells: Challenges in Electrocatalysis and Interfacial Charge Transfer. Chem. Rev. 2019;119:11945-79.

[38] Mustain WE. Understanding how high-performance anion exchange membrane fuel cells were achieved: Component, interfacial, and cell-level factors. Curr. Opin. Electrochem. 2018;12:233-39.

[39] Lilloja J, Mooste M, Kibena-Põldsepp E, Sarapuu A, Zulevi B, Kikas A, et al. Mesoporous iron-nitrogen co-doped carbon material as cathode catalyst for the anion exchange membrane fuel cell. J. Power Sources Adv. 2021;8:100052. 
[40] Li JK, Bruller S, Sabarirajan DC, Ranjbar-Sahraie N, Sougrati MT, Cavaliere S, et al. Designing the 3D Architecture of PGM-Free Cathodes for $\mathrm{H}_{2} /$ Air Proton Exchange Membrane Fuel Cells. ACS Appl. Energy Mater. 2019;2:7211-22.

[41] Gottesfeld S, Dekel DR, Page M, Bae C, Yan YS, Zelenay P, et al. Anion exchange membrane fuel cells: Current status and remaining challenges. J. Power Sources 2018;375:170-84.

[42] Mustain W, Pivovar B. Catalysts for Polymer Membrane Fuel Cells. Catalysts 2020;10:3.

[43] Omasta TJ, Park AM, LaManna JM, Zhang YF, Peng X, Wang LQ, et al. Beyond catalysis and membranes: visualizing and solving the challenge of electrode water accumulation and flooding in AEMFCs. Energy Environ. Sci. 2018;11:551-8.

[44] Kisand K, Sarapuu A, Danilian D, Kikas A, Kisand V, Rähn M, et al. Transition metalcontaining nitrogen-doped nanocarbon catalysts derived from 5-methylresorcinol for anion exchange membrane fuel cell application. J. Colloid Interface Sci. 2021;584:26374.

[45] Jaouen F, Lefevre M, Dodelet JP, Cai M. Heat-treated Fe/N/C catalysts for O-2 electroreduction: Are active sites hosted in micropores? J. Phys. Chem. B 2006;110:5553-8.

[46] Ratso S, Zitolo A, Käärik M, Merisalu M, Kikas A, Kisand V, et al. Non-precious metal cathodes for anion exchange membrane fuel cells from ball-milled iron and nitrogen doped carbide-derived carbons. Renew. Energy 2021;167:800-10.

[47] Meng HJ, Liu YM, Liu HR, Pei SP, Yuan XX, Li H, et al. ZIF67@MFC-Derived Co/NC@CNFs Interconnected Frameworks with Graphitic Carbon-Encapsulated Co Nanoparticles as Highly Stable and Efficient Electrocatalysts for Oxygen Reduction Reactions. ACS Appl. Mater. Interfaces 2020;12:41580-9.

[48] Lu L, Cao XJ, Shen ZY, Huo JJ, Chen WH, Liu CT, et al. Electrospun nitrogen-doped carbon nano fibers for electrocatalysis. Sustainable Mater.Technol. 2020;26:13.

[49] Peng W, Yang XX, Mao LC, Jin JH, Yang SL, Zhang JJ, et al. ZIF-67-derived Co nanoparticles anchored in $\mathrm{N}$ doped hollow carbon nanofibers as bifunctional oxygen electrocatalysts. Chem. Eng. J. 2021;407:11.

[50] Shang CQ, Li MC, Wang ZY, Wu SF, Lu ZG. Electrospun Nitrogen-Doped Carbon Nanofibers Encapsulating Cobalt Nanoparticles as Efficient Oxygen Reduction Reaction Catalysts. ChemElectroChem 2016;3:1437-45.

[51] Liu D, Zhang XP, Sun ZC, You TY. Free-standing nitrogen-doped carbon nanofiber films as highly efficient electrocatalysts for oxygen reduction. Nanoscale 2013;5:952831.

[52] Hanif S, Iqbal N, Shi X, Noor T, Ali G, Kannan AM. NiCo-N-doped carbon nanotubes based cathode catalyst for alkaline membrane fuel cell. Renew. Energy 2020;154:508-16.

[53] Wang CH, Yang CW, Lin YC, Chang ST, Chang SLY. Cobalt-iron(II,III) oxide hybrid catalysis with enhanced catalytic activities for oxygen reduction in anion exchange membrane fuel cell. J. Power Sources 2015;277:147-54.

[54] Li XG, Popov BN, Kawahara T, Yanagi H. Non-precious metal catalysts synthesized from precursors of carbon, nitrogen, and transition metal for oxygen reduction in alkaline fuel cells. J. Power Sources 2011;196:1717-22.

[55] Osmieri L, Zafferoni C, Wang LQ, Videla A, Lavacchi A, Specchia S. PolypyrroleDerived Fe-Co-N-C Catalyst for the Oxygen Reduction Reaction: Performance in Alkaline Hydrogen and Ethanol Fuel Cells. ChemElectroChem 2018;5:1954-65.

[56] Santori PG, Speck FD, Cherevko S, Firouzjaie HA, Peng X, Mustain WE, et al. High Performance FeNC and Mn-oxide/FeNC Layers for AEMFC Cathodes. J. Electrochem. Soc. 2020;167:13. 
[57] Lilloja J, Kibena-Põldsepp E, Sarapuu A, Douglin JC, Käärik M, Kozlova J, et al. Transition-Metal- and Nitrogen-Doped Carbide-Derived Carbon/Carbon Nanotube Composites as Cathode Catalysts for Anion-Exchange Membrane Fuel Cells. ACS Catal. 2021;11:1920-31.

[58] Yang Y, Peng HQ, Xiong Y, Li QH, Lu JT, Xiao L, et al. High-Loading CompositionTolerant Co-Mn Spinel Oxides with Performance beyond $1 \mathrm{~W} / \mathrm{cm}^{2}$ in Alkaline Polymer Electrolyte Fuel Cells. ACS Energy Lett. 2019;4:1251-7. 